\title{
Epidemiological aspects and world distribution of HTLV-1 infection
}

\section{Antoine Gessain ${ }^{1,2}$ * and Olivier Cassar ${ }^{1,2}$}

${ }^{1}$ Département de Virologie, Unité d'épidémiologie et physiopathologie des virus oncogènes, Institut Pasteur, Paris, France

${ }^{2}$ CNRS, URA3015, Paris, France

\section{Edited by:}

Toshiki Watanabe, The University of

Tokyo, Japan

\section{Reviewed by:}

Hidekatsu Iha, Oita University, Japan Masako Iwanaga, Teikyo University Graduate School of Public Health Japan

\section{*Correspondence:}

Antoine Gessain, Département de Virologie, Institut Pasteur, 28 Rue du Dr. Roux, Paris 75015, France. e-mail: antoine.gessain@pasteur.fr
The human T-cell leukemia virus type 1 (HTLV-1), identified as the first human oncogenic retrovirus 30 years ago, is not an ubiquitous virus. HTLV-1 is present throughout the world, with clusters of high endemicity located often nearby areas where the virus is nearly absent. The main HTLV-1 highly endemic regions are the Southwestern part of Japan, sub-Saharan Africa and South America, the Caribbean area, and foci in Middle East and Australo-Melanesia. The origin of this puzzling geographical or rather ethnic repartition is probably linked to a founder effect in some groups with the persistence of a high viral transmission rate. Despite different socio-economic and cultural environments, the HTLV-1 prevalence increases gradually with age, especially among women in all highly endemic areas. The three modes of HTLV-1 transmission are mother to child, sexual transmission, and transmission with contaminated blood products. Twenty years ago, de Thé and Bomford estimated the total number of HTLV-1 carriers to be 10-20 millions people. At that time, large regions had not been investigated, few population-based studies were available and the assays used for HTLV-1 serology were not enough specific. Despite the fact that there is still a lot of data lacking in large areas of the world and that most of the HTLV-1 studies concern only blood donors, pregnant women, or different selected patients or high-risk groups, we shall try based on the most recent data, to revisit the world distribution and the estimates of the number of HTLV-1 infected persons. Our best estimates range from 5-10 millions HTLV-1 infected individuals. However, these results were based on only approximately 1.5 billion of individuals originating from known HTLV-1 endemic areas with reliable available epidemiological data. Correct estimates in other highly populated regions, such as China, India, the Maghreb, and East Africa, is currently not possible, thus, the current number of HTLV-1 carriers is very probably much higher.

Keywords: HTLV-1, HTLV-1 epidemiology, HTLV-1 world distribution, HTLV-1 in Europe, HTLV-1 in Africa, HTLV-1 in the Americas, HTLV-1 in Asia, HTLV-1 in Oceania

\section{INTRODUCTION}

Very rapidly after HTLV-1 discovery and its association with adult T-cell leukemia (ATL), several studies were initiated both by American and Japanese researchers, to get insights into the distribution, the transmission modes, as well as the origin of HTLV-1.

Thus, as soon as 1982-1984, important works demonstrated clearly that Japan was a high endemic area for HTLV-1. Interestingly, since the first studies, the geographic distribution of HTLV-1 carriers is quite uneven in Japan and the greatest prevalence is observed in Southwestern Japan (Kyushu island and the Okinawa archipelago). The origin of such a peculiar distribution is still the matter of several hypotheses (Ishida and Hinuma, 1986; Miura et al., 1994; Eguchi et al., 2009; Watanabe, 2011).

Nearly concomitantly to the initial papers by the Japanese groups, the US teams demonstrated that the Caribbean area was also endemic for HTLV-1. Soon after, ATL patients were reported in the Caribbean community living in the United Kingdom (Catovsky et al., 1982). Such data, together with some early epidemiological studies showing an HTLV-1 seroprevalence in serum samples from inhabitants originating from different African countries, indicated then that such a retrovirus was also endemic in some areas of the African continent (Biggar et al., 1984; Hunsmann et al., 1984; Saxinger et al., 1984; de-The et al., 1985; de The and Gessain, 1986; Delaporte et al., 1989a,b, 1991; Ouattara et al., 1989; Verdier et al., 1989, 1994; Goubau et al., 1990; Dumas et al., 1991; Schrijvers et al., 1991).

The simian counterpart of HTLV-1 was also rapidly discovered, based on the findings of STLV-1 in several monkey species from Asia and Africa (Hunsmann et al., 1983; Guo et al., 1984; Hayami et al., 1984; Homma et al., 1984; Becker et al., 1985; Watanabe et al., 1985; Blakeslee et al., 1987; Koralnik et al., 1994).

The different transmission modes of HTLV-1 have been rapidly studied by the same groups (Kinoshita et al., 1984; Okochi et al., 1984; Hino et al., 1985; Kajiyama et al., 1986; Murphy et al., 1989; Takahashi et al., 1991; Hino, 2011). They are now rather well understood. This led to some efficient preventive measures in several countries (Ando et al., 1987; Hino et al., 1987; Inaba et al., 1989). 
In contrast, the world distribution and the global and loco-regional estimation of the HTLV-1 prevalence remain yet poorly known. This lack of knowledge is mainly due to four different factors: (1) Several large regions/areas have not been investigated for HTLV-1 infection. Thus, the prevalence remains barely unknown in many areas of the world. This is evident in some highly populated regions of Asia or in East and North Africa. (2) The assays used for HTLV-1 serology exhibited some lack of specificity leading in the 1980s-1990s to an overestimated HTLV1 prevalence. (3) Most of the works performed to appreciate the HTLV-1 prevalence are based on study of series of blood donors, pregnant women, or hospitalized patients. Population-based studies trying to estimate HTLV-1 prevalence in large areas, or even at a country level, remain very rare. (4) A very important last point is that, in most of the studied areas, HTLV-1 distribution is not homogeneous. HTLV-1 is indeed present mainly as relatively small foci or clusters with a high or very high prevalence of infection, with nearby quite low endemic areas. This has been very well exemplified in Southern Japan and in some areas of South America. Thus, to give a precise estimation of HTLV-1 prevalence in a specific country or area is relatively difficult and, in some cases, nearly impossible.

Very few studies have thus given an estimation of the HTLV1 world prevalence. Japan and the African continent have been rapidly considered, as the two regions in which HTLV-1 infected persons were the most numerous. Then, South America has also been considered as a very important focus of HTLV-1 carriers and associated diseases (mainly ATL or tropical spastic paraparesis/HTLV-1 associated myelopathy (TSP/HAM), a chronic severe neuromyelopathy). One of the most frequently quoted estimation number of infected persons is based on a paper, published in 1993 by G. de Thé and R. Bomford from our group in Pasteur (de The and Bomford, 1993). This study gave a rough estimation of 10-20 millions of HTLV-1 infected individuals worldwide. In most of the review published since then, this number is often taken as a fact (Proietti et al., 2005; Verdonck et al., 2007; Hlela et al., 2009; Watanabe, 2011).

By writing this paper, our main goal was to revisit the situation of HTLV-1 epidemiology, especially its world distribution, and its estimated prevalence. This will be based on the current data, available in 2012, thus around 30 years after the first published epidemiological studies and nearly 20 years after the last estimation of global HTLV-1 prevalence.

This ambitious work has been based on the analyses of: (1) most of the 1,100 papers referenced in PubMed on such a topic, (2) most of the available book chapters concerning HTLV-1 epidemiology but also (3) on all the abstracts (of the epidemiology sections) of the International Conference on HTLV and related viruses held since 1985 .

This study was, of course, possible thanks to our expertise and experience in the field since 30 years for one of us and nearly 10 years for the other one.

After presenting the different methods used for the epidemiological studies of HTLV-1 infection, we shall describe briefly the major epidemiological determinants and the different transmission modes of this human retroviral infection. Then, a small chapter will report the major findings concerning the molecular epidemiology of HTLV-1, which possesses an unusual great genetic stability for a retrovirus. Lastly, we shall try to present, with a table and a map, the HTLV-1 worldwide distribution and its prevalence estimates by continent and by country when possible.

\section{METHODS FOR HTLV-1 EPIDEMIOLOGY}

Most of the studies were performed on series of blood donors, pregnant women, or hospitalized patients. In few cases, population-based studies were done in some villages, towns, or even regions of a given country. The epidemiological and demographic characteristics of blood donors could be very different according to the countries: indeed, they can be quite representative of the middle-class population in some countries but in other areas, either they are mainly family members of hospitalized patients, or they originate from low socio-economic populations and are sometimes paid to give blood and, lastly, in several areas (especially in some African studies) they are mainly young men. HTLV-1 prevalence varies according to age, sex, and economic level in most of HTLV-1 endemic areas. Thus, the prevalence found in blood donors can be, of course, useful, but provides not always the best data to estimate precisely the HTLV-1 prevalence in a given country. The real prevalence is very probably higher than that found in blood donors in most of the cases. Thus, the data based on pregnant women are generally more useful to compare the situation between different areas or countries as first, it is quite representative of a given region and second, the mean age of pregnant women is generally comparable (about 22-26 years) in most of the countries. The studies in general populations, in or out-adult patients, can also be very useful to try to appreciate the HTLV1 prevalence in a given area as, in the great majority, the tested patients do not suffer of the very rare diseases linked specifically to HTLV-1 infection.

Diagnostic methods used for the study of HTLV-1 infection include mainly serological assays searching for antibodies directed specifically against different HTLV-1 antigens. Screening tests are usually Enzyme-Linked Immunoabsorbent Assay (ELISA) or Particle Agglutination (PA). Confirmatory tests are immunofluorescence (IFA), but mostly Western Blot (WB), or Innogenetics line immunoassay (INNO-LIA). Moreover, research of integrated provirus, in the DNA from peripheral blood cells, could be done by qualitative and/or quantitative polymerase chain reaction (PCR). Despite some improvements in the WB assays specificity during the last two decades, indeterminate serological patterns remain frequent following WB analysis, and represent an important concern for routine screening in blood banks in Europe, the Americas, and some parts of Africa. It is also of course a major issue for comparative analyses between epidemiological studies performed in both low and high endemic areas, especially in intertropical areas (Mauclere et al., 1997; Filippone et al., 2012). The significance of these frequent indeterminate $\mathrm{WB}$ can be various but, in the majority of the cases, remains mostly unknown and a matter of debate reviewed in Filippone et al. (2012). Indeed, in rare cases, these patterns have been associated to (i) HTLV-1 but mostly HTLV-2 infection exhibiting an atypical HTLV-serology, (ii) HTLV-1 seroconversion, (iii) infection by a different retrovirus such as the recently discovered HTLV-3 or HTLV-4 (Mahieux and Gessain, 2009). Furthermore, some have been considered as the 
results of cross-reactivity against other microbial agents, especially Plasmodium falciparum in Central Africa and Indonesia (Porter et al., 1995; Mahieux et al., 2000). In this review, we shall take into account, in the great majority, only the studies in which HTLV-1 infection has been confirmed by a specific test, mostly a WB.

\section{MAJOR EPIDEMIOLOGICAL DETERMINANTS OF HTLV-1}

HTLV-1 is not an ubiquitous virus. Indeed, it is present throughout the world, with clusters of high endemicity located often nearby areas where the virus is nearly absent. In these foci, the HTLV-1 seroprevalence in adults is estimated to be at least $1-2 \%$ but it can also reach $20-40 \%$ in persons older that 50 years in some specific clusters. The main very highly endemic areas are the Southwestern part of Japan, some parts of the Caribbean area, and its surroundings regions, foci in South America including especially parts of Colombia and French Guyana, some areas of intertropical Africa (such as South Gabon) and of the middle East (such as the Mashad region in Iran), and rare isolated clusters in Australo-Melanesia. In Europe, only Romania seems to represent an HTLV-1 endemic region. The origin of this puzzling geographical or rather ethnic repartition is not well understood but is probably linked to a founder effect in some groups, followed by the persistence of a high viral transmission rate.

Interestingly and despite different socio-economic and cultural environments, HTLV-1 seroprevalence increases gradually with age, especially in women, in all the highly endemic areas. The general increase with age may be related to a cohort effect, as well as demonstrated in Japan, while the increase in women might also be due to an accumulation of sexual exposures with age (Blattner et al., 1986; Chavance et al., 1989; Ueda et al., 1989; Mueller, 1991; Murphy et al., 1991).

Three modes of transmission have been demonstrated for HTLV-1. (1) Mother to child transmission, which is mainly linked to a prolonged breast-feeding after 6 months of age (Hino, 2011). Ten to $25 \%$ of the breast-fed children born from HTLV-1 infected mothers will become infected. High level of HTLV-1 proviral load in milk, in blood cells as well as high HTLV-1 antibody titers in the serum, and long duration of breast-feeding (at least $>6$ months) represent major risk factors for HTLV-1 transmission from mother to child (Takahashi et al., 1991; Hino et al., 1994; Ureta-Vidal et al., 1999; Li et al., 2004). (2) Sexual transmission, which mainly, but not exclusively, occurs from male to female, and is thought to be responsible for the increased seroprevalence with age in women (Murphy et al., 1989; Stuver et al., 1993; Takezaki et al., 1995; Kaplan et al., 1996; Roucoux et al., 2005). (3) Transmission with contaminated blood products (containing HTLV-1 infected lymphocytes), which is responsible for an acquired HTLV-1 infection among a high proportion (15-60\%) of the blood recipients (Okochi et al., 1984; Inaba et al., 1989). HTLV-1 infection is also present among intravenous drug users but at a lesser extent than HTLV-2 (Murphy et al., 1999).

\section{HTLV-1 MOLECULAR EPIDEMIOLOGY: PRESENCE OF GEOGRAPHICAL/ETHNIC RELATED SUBTYPES/GENOTYPES}

On a molecular point of view, HTLV-1 possesses a remarkable genetic stability, an unusual feature for a retrovirus. Viral amplification via clonal expansion of infected cells, rather than by reverse transcription is, very probably, the reason for this striking genetic stability. The low sequence variation of HTLV-1 can be used as a molecular tool to follow the migrations of infected populations in the recent or distant past and thus to gain new insights into the origin, evolution, and modes of dissemination of such retroviruses and of their hosts (Gessain et al., 1992b; Yanagihara, 1994). The few nucleotide substitutions observed among virus strains are indeed specific to the geographic origin of the patients rather than the pathology. Four major geographic subtypes (genotypes) have been reported. They include the Cosmopolitan subtype A, the Central African subtype B, the Central African/Pygmies subtype D, and the Australo-Melanesian subtype C. A limited number of strains found in Central Africa belong to other rare subtypes (E, F, G). The Cosmopolitan subtype A, which comprised several geographical subgroups (Japanese, West Africa, North African...) is the most widespread, being endemic in Japan, the Caribbean area, Central and South America, North and West Africa as well as part of the Middle East. The sequence variability within subtype A is very low. This is very likely to reflect a relatively recent dissemination (some centuries to few millenium) of this genotype from a common ancestor. The Australo-Melanesian subtype $\mathrm{C}$ is the most divergent. This result reflects a long period of evolution (at least several millenium) in isolated populations living in different islands of the Pacific area. The appearance of these HTLV-1 subtypes in humans was strongly suggested to be linked to interspecies transmission between STLV-1 infected monkeys and humans, followed by variable period of evolution in the human host (Salemi et al., 1998; Vandamme et al., 1998; Meertens et al., 2001; Nerrienet et al., 2001; Wolfe et al., 2005). Indeed, STLV-1, the simian counterpart of HTLV-1, infects several species of non-human primates (NHPs) of the Old Word, ranging from chimpanzees, orangutans, and gorillas to mandrills, as well as several African small monkey species and a wide range of macaques, and other Asian monkeys. Interestingly, STLV-1 infection was also associated to the development of ATL in some NHPs.

A map of the different HTLV-1 molecular subtypes and places of possible interspecies transmissions from STLV-1 infected monkeys to humans is presented on Figure 1.

There is so far no solid evidence that either a particular specific mutation or a genotype is associated with the development of a TSP/HAM or an ATL, in an asymptomatic carrier. Data concerning level of transmission or proviral load according to molecular subtypes need to be performed.

\section{HTLV-1 WORLDWIDE DISTRIBUTION AND PREVALENCE ESTIMATES BY GEOGRAPHICAL AREA}

To give a general overview of the HTLV-1 worldwide distribution was relatively easy for most of the regions. However, to try to provide an estimate, even rough, of the number of HTLV-1 infected persons in the different world areas, even in well-studied high HTLV-1 endemic regions was not at all an easy task. In all the cases, such estimates must be absolutely taken with cautious. Indeed, as said above, very few large population-based studies have been done and most of the analyzed studies concern mainly blood donors, pregnant women, or populations of different in or outadult patients not really representative of the population of a given 

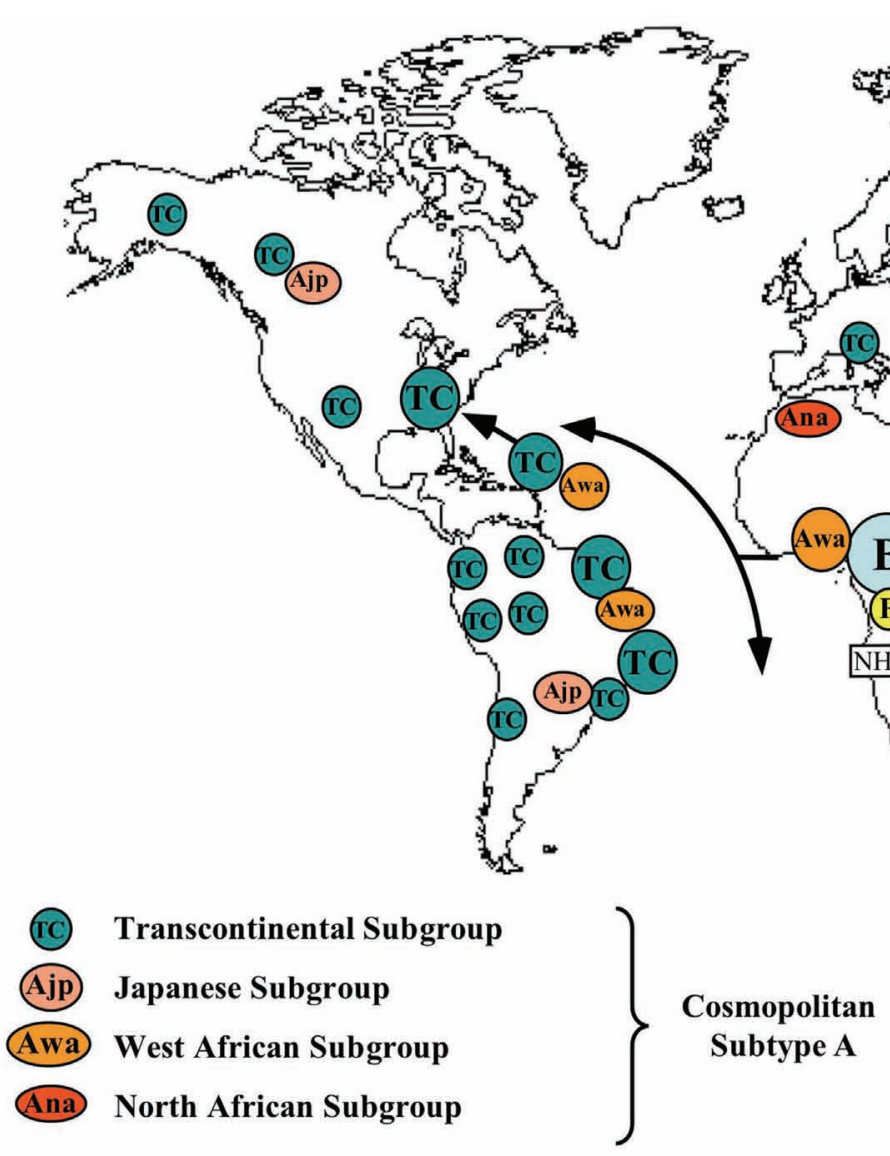

FIGURE 1 | Map of the geographical distribution of HTLV-1 subtypes (A-G), and the main modes of viral dissemination by movements of infected populations. Small arrows indicate the very probable interspecies transmission of STLV-1 (S) from monkeys to Humans $(H)$ at the origin of some current HTLV-1 subtypes. These different subtypes comprise the Cosmopolitan A subtype with its different subgroups: TC (Transcontinental being the most frequent and widespread one), Awa (West African), Ana (North African), Ajp (Japanese), B or Central African
(B) Subtype B

(C) Subtype C

(D) Subtype D

(E) Subtype E

STLV-1 Transmission

from Non-Human

Primates to Humans

(F) Subtype F

(G) Subtype G

being the most frequent in this large endemic area, $\mathrm{C}$ or AustraloMelanesian D, also from Central Africa and present especially in certain Pygmy groups and lastly E, F, G with very few strains yet reported (all in Central Africa). The main HTLV-1 molecular epidemiological studies used to draw this map are the following ones: (Gessain et al., 1991; Gasmi et al., 1994; Miura et al., 1994; Mahieux et al., 1997, 1998; Salemi et al., 1998; Vandamme et al., 1998; Wolfe et al., 2005; Cassar et al., 2007; Gessain, 2011).

area or country on an epidemiological point of view (Table 1 and Figure 2).

\section{HTLV-1 IN EUROPE}

Europe represents around 400 millions of persons. Numerous epidemiological studies have been performed in this continent, mainly in blood donors and in pregnant women (Courtois et al., 1990; Courouce et al., 1993; Nightingale et al., 1993; Zaaijer et al., 1994; Dalekos et al., 1995; Ferrante et al., 1997; Hale et al., 1997; Tuset et al., 1997; Poljak et al., 1998; Ades et al., 2000; Machuca et al., 2000; Tseliou et al., 2004, 2006; Vrielink and Reesink, 2004; Taylor et al., 2005; Davidson et al., 2006; Laperche et al., 2009; Brant et al., 2011). Furthermore, several large series of ATL and TSP/HAM have been reported (Gout et al., 1989; Rio et al., 1990; Plumelle et al., 1993; Martin et al., 2010; Ceesay et al., 2012). The most studied countries are the United Kingdom (UK), Metropolitan France, and Spain. Based on all these works, it is now clear that most (at least more than $80 \%$ ) of the persons infected by HTLV1 living currently in Europe originate directly, or are children or descendents of immigrants, from a high endemic area, mostly West Indies and Africa. Thus, in UK, most of HTLV-1 carriers originate from the former British West Indies, especially Jamaica and also, at a lesser extent, Barbados, Trinidad, and Tobago (Catovsky et al., 1982; Payne et al., 2004; Dougan et al., 2005). More rarely, they originate from West Africa as Ghana or Sierra Leone. Concerning Metropolitan France, most of the persons originate from French West Indies as Martinique or Guadeloupe (Gout et al., 1989; Gessain et al., 1990c; Rio et al., 1990; Plumelle et al., 1993). They can also originate from West or Central Africa as Senegal, Mali, Guinea, Côte d'Ivoire, or Cameroon (Gessain et al., 1990b, 1992a; Rio et al., 1990; Mahe et al., 1994; Duval et al., 2010). It is important to note that in blood donors and, thus, very probably in the general population, a certain proportion of infected persons are women, of Caucasian background, that 
Table 1 | HTLV-1 seroprevalence among pregnant women originating from HTLV-1 endemic countries in Africa, West Indies, North and South America, Asia, and Europe.

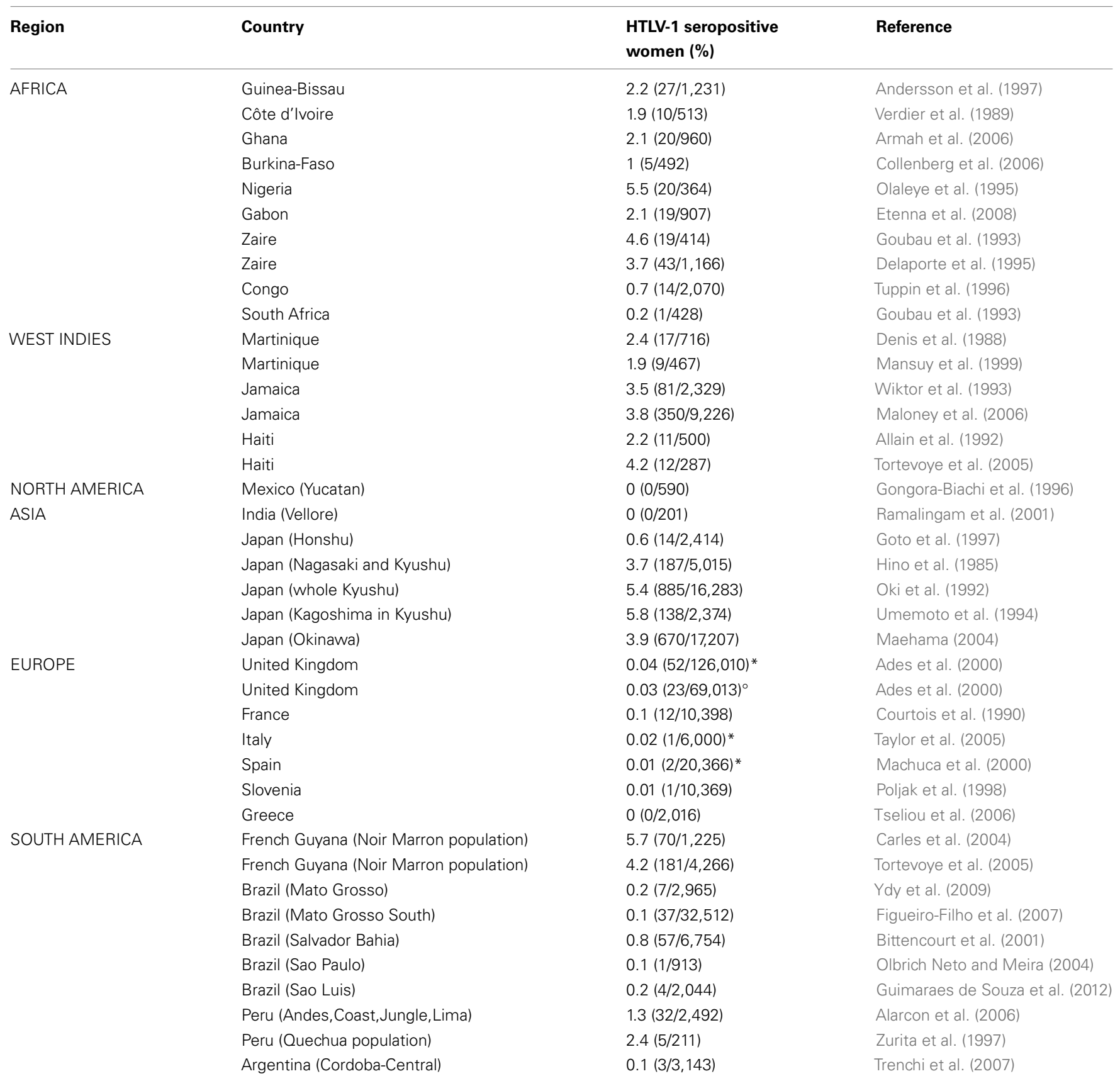

The quoted studies are, to our knowledge, among the most representative and reliable ones to date.

*including black African and Afro-Caribbean women.

-Women born exclusively in the United Kingdom.

have acquired HTLV-1 through sexual contacts with a partner originating from an HTLV-1 endemic area. This situation can represent around $5-10 \%$ in different European countries including France or UK (Dougan et al., 2005). In Spain, the situation is slightly different as, due to historical reasons, most of the HTLV1 infected persons are from South America (Toro et al., 2002; Padua et al., 2011; Trevino et al., 2012). However the prevalence seems much lower than in UK or in Metropolitan France. In Portugal, this is about the same but, in some cases, the HTLV1 infected persons can originate from ancient African colonies such as Mozambique and Angola (Padua et al., 2011). Intravenous drug users represent also a population relatively endemic for HTLV-1, specially in Spain, Italy, and Ireland even if HTLV2 is always much more prevalent in such a specific population 


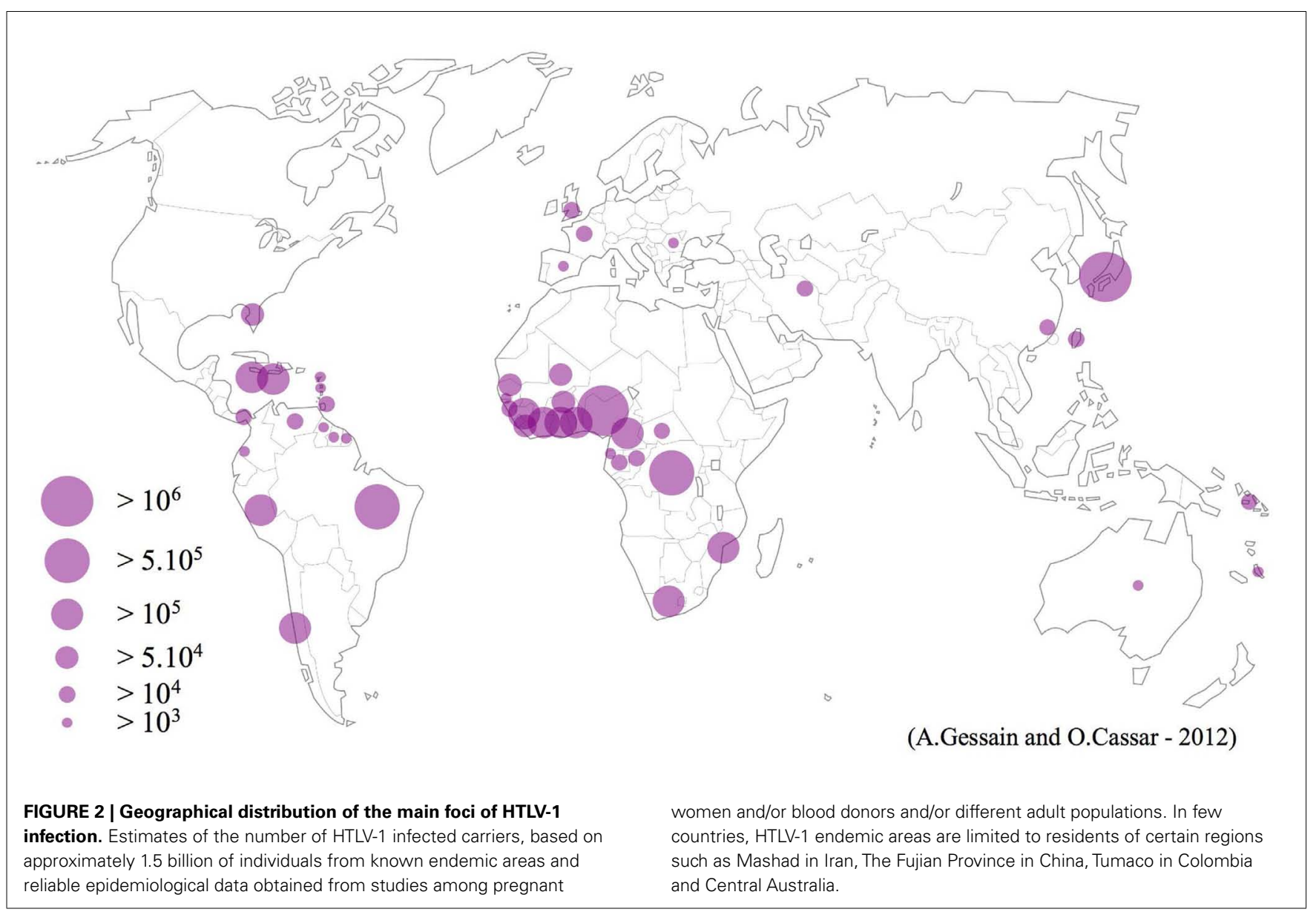

(Gradilone et al., 1986; Calderon et al., 1995; Chironna et al., 1996).

The level of HTLV-1 infection in most of the other European countries is very low as demonstrated by an HTLV-1 prevalence in first-time blood donors of less than $0.4 / 10,000$ and a great rarity of ATL or TSP/HAM reports (Laperche et al., 2009). The only exception seems to be Romania, which appears to be the only true HTLV-1 endemic area in Europe (Paun et al., 1994; Veelken et al., 1996). Indeed, a prevalence of 5.3/10,000 donations has been recently reported among first-time blood donors in this East European country (population of 22 millions; Laperche et al., 2009). HTLV-1 infection in polytransfused patients is also quite high ranging from 3 to $25 \%$. Furthermore, series of cases of ATL or TSP/HAM have been reported in Romania. Lastly, sporadic cases have also been seen in immigrants from this country living in other European countries (Veelken et al., 1996; Manca et al., 1997). These data, taken together, demonstrate clearly a relatively high level of HTLV-1 infection in this country. The origin of such situation remains unknown and the matter of different hypotheses.

The estimation of the number of HTLV-1 infected persons in Europe is a very difficult exercise. Based on all data from UK and especially their numerous studies, the team of Graham Taylor suggests that 20,000-30,000 people have HTLV-1 infection in the UK (Ades et al., 2000). Concerning Metropolitan France, based on the study on prevalence in blood donors, pregnant women,

and the incidence of ATL cases, we can estimate that it is roughly equivalent with around 10,000-25,000 HTLV-1 infected persons. Importantly and, as in the UK, most of them are undiagnosed. Concerning Romania, this is more difficult, due to the few available studies. However, in a recent study, the prevalence in the first-time blood donors seems 10 times more in Romania than in UK and Metropolitan France (Laperche et al., 2009). A rough minimal estimation of few thousands with a wide range $(3,000-15,000)$ can be proposed. However, we cannot rule out the presence of possible HTLV-1 clusters, or foci, in some specific areas or populations in such country.

\section{HTLV-1 IN AFRICA}

The total population of Africa is estimated at a little more than 1 billion in 2012. The African population has grown a lot over the past century. Indeed, the population doubled for the period 19822009 and quadrupled during the years 1955-2009. Thus, more than $40 \%$ of the population is below 15 years old in most subSaharan countries. Africa is probably the largest endemic area for HTLV-1. However, despite numerous epidemiological studies and reports of sporadic cases or even small series of ATL and TSP/HAM cases, the situation concerning the level of HTLV-1 infection, is not really known in several countries and regions of this large continent. Indeed, very few large studies on representative general population are available. 
Here, we shall first briefly report the situation, based on the most solid studies (large populations of mainly blood donors, pregnant women, or adult hospitalized patients or control groups, and robust serological tests including mainly a WB for confirmation), according to five large geo-climatological areas: North Africa, West Africa, Central Africa, East Africa, and lastly South Africa. Then, we shall try to estimate the number of HTLV-1 infected persons in some specific countries for which reliable data are available.

\section{North Africa/Maghreb}

The very few studies concern mainly blood donors or multitransfused patients from Egypt, Morocco, and Tunisia where the HTLV-1 seroprevalence appears to be very low or negative (Saxinger et al., 1984; de-The et al., 1985; de The and Gessain, 1986; El-ghazzawi et al., 1987; el-Farrash et al., 1988; van Doornum et al., 1990; Mojaat et al., 1999; Kawashti et al., 2005; Stienlauf et al., 2009). Very few cases of ATL or TSP/HAM have been reported in such countries, including at least Morocco and Egypt, either diagnosed locally or in immigrants, especially in France (Thyss et al., 1990; Gasmi et al., 1994; Gharibi et al., 2011). In summary, based on the scarce available data, Morocco seems to be, in North Africa, the only country that can be considered as HTLV-1 endemic, however at a low level and a reliable estimation of the number of HTLV-1 infected persons in North Africa is currently impossible.

\section{West Africa}

This large area comprises 16 countries: Benin, Burkina-Faso, Cape Verde, Côte d'Ivoire, Gambia, Ghana, Guinea and Guinea-Bissau, Liberia, Mali, Mauritania, Niger, Nigeria, Senegal, Sierra Leone, and Togo. This represents more than 300 millions of inhabitants. Several large studies have been performed in Senegal, GuineaBissau, Côte d'Ivoire, Ghana, and Nigeria. Furthermore, ATL and/or TSP/HAM have been reported in most of these countries including especially Senegal, Mauritania, Mali, Côte d'Ivoire, Nigeria (Fleming et al., 1986; Gessain et al., 1990a,c; Williams et al., 1993, 1994; Mahe et al., 1994; Michel et al., 1996; Analo et al., 1998; Fouchard et al., 1998; Sene-Diouf et al., 2000). The HTLV-1 seroprevalence in blood donors ranged mainly from 0.2 to $3 \%$. However, in most of these studies, blood donors are mainly young men. In Senegal, based on a study of 4,900 blood donors, HTLV-1 seroprevalence was of $0.16 \%$, however most of the infected donors originated from the South of the country, where the prevalence reached 1\% (Diop et al., 2006). In Guinea, it was of 1.2\% (22/1,785; Gessain et al., 1993a), while in Côte d'Ivoire and Ghana it ranges from 0.5 to $2 \%$ depending on the studies (Ouattara et al., 1989; Verdier et al., 1989; Biggar et al., 1993; Sarkodie et al., 2001; Ampofo et al., 2002; Armah et al., 2006). In Nigeria, it varies from 0.7 to $3.7 \%$ according to geographical location (Fleming et al., 1986; Analo et al., 1998). Other studies were performed on pregnant women or representative general adult population or on different control groups. The HTLV-1 prevalence was around 1\% in Guinea, with variations from 0.2 to $1.9 \%$ depending on the region (Jeannel et al., 1995), and ranged from 2.2 to $3.6 \%$ in Guinea-Bissau (Andersson et al., 1997; Larsen et al., 2000; da Silva et al., 2009). It was of 1.2\% in Gambia (Del Mistro et al., 1994) and ranged from 0.2 to $1.2 \%$ in Senegal (Hunsmann et al., 1984). It was of $1 \%$ in
Burkina-Faso (Collenberg et al., 2006) and ranged from 1 to $1.6 \%$ in Liberia, Togo and Benin (Hunsmann et al., 1984; Dumas et al., 1991; Verdier et al., 1994; Houinato et al., 1996), and from 1 to $2.7 \%$ in Côte d'Ivoire and Ghana according to the type of studies (Ouattara et al., 1989; Verdier et al., 1989, 1994; Biggar et al., 1993; Goubau et al., 1993; Armah et al., 2006) and reached 5.5\% in Nigeria (Olaleye et al., 1994, 1995). The estimates of the number of HTLV-1 infected persons in most of the West African countries are given in Table 2.

\section{Central Africa}

This area comprises nine countries including, Angola, Cameroon, Central African Republic (CAR), Chad, Democratic Republic of the Congo (DRC) formerly Republic of Zaire, Equatorial Guinea, Gabon, Republic of the Congo, Sao-Tome-et-Principe. This represents around 130 millions of persons. Several important epidemiological studies have been performed in Cameroon and especially in Gabon. Cases of ATL and/or TSP/HAM have been reported mainly in Cameroon, Gabon and the DRC (Kayembe et al., 1990; Jeannel et al., 1993). HTLV-1 prevalence in adults living in Cameroon ranges globally from 0.5 to $2 \%$ depending on the geographical location, the studied population, and the ethnic group (Mauclere et al., 1997; Mauclère et al., 2011; Filippone et al., 2012). Indeed, the Pygmies groups, who live mainly in the Southern region of this country, have a much higher level of HTLV-1 prevalence (around of $2-10 \%$ in adults depending on age) than the Bantu groups (around $0.3-1.5 \%$ ), who represent most of the population of this area (Mauclere et al., 1997; Mauclère et al., 2011; Filippone et al., 2012). In Gabon, several studies of different representative urban or rural populations have been performed (Delaporte et al., 1988, 1991; Bertherat et al., 1998). This is the best-studied country for Africa concerning the HTLV-1 infection. All the data indicated a global high HTLV-1 seroprevalence of around 5-10\% in the adult populations (Delaporte et al., 1988, 1991; Bertherat et al., 1998). In pregnant women it ranged from 1 to $5 \%$ according to the geographical location (Schrijvers et al., 1991; Etenna et al., 2008). Based on several studies, it appears clearly that the Haut-Ogoué region (a Southeastern area of the country) is the highest endemic area of Gabon for HTLV-1 infection. Indeed, in some villages of this region, the HTLV-1 seroprevalence can reach more than $25 \%$ in elder adults, especially women (Delaporte et al., 1989b; Le Hesran et al., 1994). This area represents very probably the highest yet known HTLV-1 endemic area in the African continent. In CAR, HTLV-1 infection has been reported in Pygmies from the Southern region (Gessain et al., 1993b) and a seroprevalence of $7 \%$ has been recently shown in aged adults ( $>55$ years old) of the same rain forest area (Pepin et al., 2010). In the Republic of the Congo and in DRC, HTLV-1 prevalence in pregnant women ranged from 0.7 to $3.7 \%$ depending on the studies (Delaporte et al., 1995; Tuppin et al., 1996). Furthermore, several other reports from DRC indicated that a relatively high HTLV-1 prevalence (5 to more than $20 \%$ ) in different adult populations including hospitalized patients, prostitutes, leprosy patients (Kayembe et al., 1990; Wiktor et al., 1990; Delaporte et al., 1995; Lechat et al., 1997). Such results depended widely on the geographical areas of the tested persons with high prevalence region (as the Haut-Zaire/Equateur) and low prevalence ones (Goubau et al., 1993; Delaporte et al., 1995). The 
Table 2 | Estimates of the number of HTLV-1 infected carriers, based on approximately $\mathbf{1 . 5}$ billion of individuals from known HTLV-1 endemic areas and reliable epidemiological data obtained from studies performed among pregnant women and/or blood donors and/or different adult populations.

\begin{tabular}{|c|c|c|c|}
\hline \multirow{2}{*}{$\begin{array}{l}\text { Continent/ } \\
\text { Country }\end{array}$} & \multirow[t]{2}{*}{ Population! } & \multicolumn{2}{|c|}{ HTLV-1 range } \\
\hline & & & \\
\hline Senegal & $12,969,606$ & 30,000 & 105,000 \\
\hline Gambia & $1,840,454$ & 2,500 & 13,000 \\
\hline Guinea-Bissau & $1,628,603$ & 12,000 & 28,000 \\
\hline Guinea & $10,884,958$ & 75,000 & 150,000 \\
\hline \multicolumn{3}{|l|}{ Liberia } & 100,000 \\
\hline Côte d'Ivoire & $21,952,093$ & 130,000 & 250,000 \\
\hline Ghana & $25,241,998$ & 125,000 & 375,000 \\
\hline Togo/Benin & $6,961,049 / 9,598,787$ & 80,000 & 160,000 \\
\hline Burkina Fasso & $17,275,115$ & 42,000 & 125,000 \\
\hline Mali & $14,533,511$ & 32,000 & 95,000 \\
\hline Nigeria & $170,123,740$ & 850,000 & $1,700,000$ \\
\hline Cameroon & $20,129,878$ & 80,000 & 180,000 \\
\hline Eq. Guinea & 685,991 & 1,500 & 4,500 \\
\hline Gabon & $1,608,321$ & 16,000 & 30,000 \\
\hline CAR & $5,057,208$ & 15,000 & 30,000 \\
\hline DRC & $73,599,190$ & 600,000 & $1,300,000$ \\
\hline Republic of & $4,366,266$ & 12,000 & 36,000 \\
\hline \multicolumn{4}{|l|}{ The Congo } \\
\hline Mozambique & $23,515,934$ & 120,000 & 360,000 \\
\hline South Africa & $48,810,427$ & 180,000 & 540,000 \\
\hline \multicolumn{4}{|l|}{ ASIA } \\
\hline China (Fujian & $35,110,000$ & 2,000 & 20,000 \\
\hline \multicolumn{4}{|l|}{ Province) } \\
\hline Japan* & $127,368,088$ & $1,080,000$ & $1,300,000$ \\
\hline $\begin{array}{l}\text { Iran (Mashad } \\
\text { area) }\end{array}$ & $78,868,711$ & 10,000 & 40,000 \\
\hline Taiwan & $23,113,901$ & 10,000 & 30,000 \\
\hline \multicolumn{4}{|l|}{ EUROPE } \\
\hline United & $63,047,162$ & 20,000 & 30,000 \\
\hline \multicolumn{4}{|l|}{ Kingdom** } \\
\hline France & $65,630,692$ & 15,000 & 25,000 \\
\hline Spain & $47,042,984$ & 1,000 & 8,000 \\
\hline Romania & $21,848,504$ & 3,000 & 15,000 \\
\hline \multicolumn{4}{|c|}{ CARIBBEAN REGION } \\
\hline Haiti/Dominican & $9,801,664 / 10,088,598$ & 150,000 & 350,000 \\
\hline \multicolumn{4}{|l|}{ Republic } \\
\hline Jamaica & $2,889,187$ & 100,000 & 140,000 \\
\hline Guadeloupe $^{\#}$ & 401,730 & 3,000 & 6,000 \\
\hline Martinique $^{\#}$ & 395,953 & 3,000 & 6,000 \\
\hline Trindad and & $1,226,383$ & 9,000 & 18,000 \\
\hline
\end{tabular}

\section{NORTH AMERICA}

\begin{tabular}{lccc}
\hline United States & $313,847,465$ & 90,000 & 100,000 \\
CENTRAL AND SOUTH AMERICA & & \\
Panama & $3,510,045$ & 3,500 & 25,000
\end{tabular}

(Continued)
Table 2 | Continued

\begin{tabular}{llll}
\hline $\begin{array}{l}\text { Continent/ } \\
\text { Country }\end{array}$ & Population! & \multicolumn{2}{c}{ HTLV-1 range } \\
\hline $\begin{array}{l}\text { Colombia } \\
\text { (Tumaco area) }\end{array}$ & 45,594 (est.1988) & 1,000 & 1,500 \\
$\begin{array}{l}\text { Venezuela } \\
\text { Suriname }\end{array}$ & $28,047,938$ & 14,000 & 70,000 \\
French Guyana & 560,157 & 3,000 & 7,000 \\
Guyana & 217,000 & 2,000 & 5,000 \\
$\begin{array}{l}\text { Peru } \\
\text { Brazil }\end{array}$ & 741,908 & 2,000 & 5,000 \\
Chile & $29,549,517$ & 150,000 & 450,000 \\
AUSTRALO-MELANESIA & 300,000 & 800,000 \\
Australia & $205,716,890$ & 90,000 & 250,000 \\
(Aboriginal & 463,900 & & \\
Australians) & & 2,500 & 5,000 \\
Solomon & 584,578 & & \\
Islands & & & \\
Vanuatu & 227,574 & 3,000 & 6,000 \\
Total & $1,567,570,505$ & $4,520,250$ & \\
& & & 1,000 \\
\hline
\end{tabular}

The HTLV-1 ranges were estimated combining the prevalence rates deduced from the above studied populations and the global repartition of individuals by age and sex in each studied country. In some highly populated countries and regions, such as China, India, the Maghreb and East Africa, correct estimates are currently not possible. Thus, the current total number of HTLV-1 carriers in the world is very probably much higher. Eq. Guinea, Equatorial Guinea; CAR, Central African Republic.

!According to the CIA World Factbook 2012 estimations (www.cia.gov).

*According to Satake et al. (2012).

**According to Brant et al. (2011).

"According to the National Institute of Statistics and Economic Studies 2011 estimations (www.insee.fr).

prevalence of HTLV-1 in Chad seems quite lower (around 0.5$1 \%$ in adults in the Southern part). The situation in Angola is less known. The estimates of the number of HTLV-1 infected persons in Cameroon, Gabon, Equatorial Guinea, CAR, DRC and the Republic of The Congo are given in Table 2.

\section{East Africa}

This large area comprises 12 countries including: Burundi, Erythrea, Ethiopia, Kenya, Malawi, Mozambique, Rwanda, Somalia, Tanzania, Uganda, Zambia, and Zimbabwe. Relatively few studies on HTLV-1 infection (with the exception of Mozambique) have been performed in such a large and highly populated region (total of more than 330 millions of inhabitants). Moreover, only sporadic cases of ATL and/or TSP/HAM have been reported from East African countries. Lastly, this region appears globally much less endemic for HTLV-1 than West and Central Africa. The reasons of such a situation are unknown. Indeed, all the studies performed in the countries, North of Malawi, indicate a very low or an absence of HTLV-1 infection. As examples, a nationwide community-based survey performed in Rwanda on more than 2,500 samples indicated an HTLV-1 seroprevalence of $0.2 \%$ (Group, 1989), and in Zimbabwe, only one blood donor out of 931 
(0.1\%) was found HTLV-1 seropositive (Houston et al., 1994). The situation in Mozambique (a country of 24 millions) appears different. Indeed, a study on 2,019 blood donors from Maputo city reported an HTLV-1 seroprevalence of 0.9\% (Gudo et al., 2009). Another study in blood donors found an HTLV-1 seroprevalence rate, among 15- to 49-year-old men and women respectively of 0.9 and 1.2\% (Cunha et al., 2007). A study on 752 individuals attending public heath centers from different areas of this country found a seroprevalence of $2.3 \%$ with geographical regional variation (Caterino-de-Araujo et al., 2010). Furthermore, some cases of TSP/HAM have been reported in Mozambique (Engelbrecht et al., 1999) and HTLV-1 infection has been seen at a rate of around $4 \%$ in HIV infected patients (Bhatt et al., 2009). The estimation of the number of HTLV-1 infected persons can be done only for Mozambique (Table 2).

\section{South African region}

This area comprises only three countries: Botswana, Namibia, and South Africa. Several studies have been performed but concern only South Africa, a country of 48 millions of inhabitants.

Indeed, several sporadic case or series of ATL, TSP/HAM, or infective dermatitis have been reported in South African patients (Bhigjee et al., 1990, 1993; Joubert et al., 1991; Jogessar et al., 1992). Indeed, as soon as 1999, around 200 black patients with a TSP/HAM have been seen in Durban. Furthermore, several studies performed in blood donors indicated an HTLV-1 seroprevalence ranging from 0 to $5 \%$ according to the type of tested population (black, white, young men, geographical location...; Bhigjee et al., 1993). A community-based seroprevalence survey done in adults from Natal/KwaZulu found a seroprevalence of 2.6\% (26/1,018; Bhigjee et al., 1993). Similar results (0.5-3\%) have been found in adults in other districts of this state and other states of the country (Bhigjee et al., 1994; Taylor et al., 1996; van der Ryst et al., 1996). The estimate of the number of HTLV-1 carriers in South Africa is given on Table 2.

Concerning the islands of the Indian Ocean, very few data are available. The situation is barely unknown in Madagascar, Comoros, and Mauritius but, to our knowledge, no case of ATL or TSP/HAM has been reported from these countries. It is different for the Reunion Island (an overseas French department of approximately 800,000 inhabitants) and the Seychelles archipelago. Indeed, in the Reunion Island, despite that few cases of TSP/HAM and ATL have been reported (Cnudde et al., 1991; Mahieux et al., 1994), a study on 3,900 blood donors (mostly young adult males) indicated only one infected person (Mahieux et al., 1994). By contrast, in the Seychelles, a cluster of TSP/HAM cases has been described as well as an HTLV-1 seroprevalence of 3-5\% in blood donors (Roman et al., 1987; Lavanchy et al., 1991).

\section{HTLV-1 IN THE AMERICAS}

\section{North America}

Most of the available studies on HTLV-1 prevalence in the United States, concern blood donors and intravenous drug users. In one of the first large study, nearly 40,000 blood donors in eight geographically diverse areas were screened for HTLV-1. Only 10 of them $(0.025 \%)$ showed evidence of HTLV-1 infection (Williams et al., 1988). Seroprevalence rates ranged from 0 to $0.1 \%$ at the locations sampled, with HTLV-1 antibodies found predominantly in donors from the Southeastern and Southwestern United States. The Retrovirus Epidemiology Donor Study group (REDS) evaluated, during 1991-1995, the HTLV-1 prevalence among 1.7 million donors from five REDS blood centers to $0.009 \%$ (Schreiber et al., 1997). In 2001, another study reported that the HTLV-1 seroprevalence rate among 21,000 individuals representing various patient populations including blood donors was $0.02 \%$ (Poiesz et al., 2001). HTLV-1, but mostly HTLV-2, infections are highly endemic among intravenous drug users in certain urban areas of the country (e.g., New Jersey), with seroprevalence rates reaching nearly 20\% (Freeman et al., 1995). Among them, African-Americans were significantly more likely than Hispanics and other racial groups to be HTLV-1 positive (Lee et al., 1990; Cantor et al., 1991). The first patient with ATL, initially thought to have a Sezary's syndrome and from whom HTLV-1 was first isolated, was described in 1980 in the United States (USl Poiesz et al., 1980). Typical ATL cases were detected among US native-born patients (Blayney et al., 1983; Dosik et al., 1988) and the first description of ATL in members of a single family from the US occurred in 1988 (Denic et al., 1988). Concerning TSP/HAM, small series of cases were published since 1988 (Bhagavati et al., 1988; Janssen et al., 1991). Later, larger series of ATL and TSP/HAM cases have been described in the US and most of the cases were identified in African-American individuals from the Southeastern states such as Florida (Harrington et al., 1995). A study estimates the number of HTLV-1 and 2 infected persons at around 260,000 and that they are likely more than 3,600 people in the United States with unrecognized TSP/HAM (Orland et al., 2003). It remains difficult to provide a solid estimate for HTLV-1 in the USA (Table 2).

HTLV-1 seems to be rare in Canada and the number of HTLV-1 cases is unknown. Nevertheless, the HTLV-1 prevalence observed among 168,668 blood donors in the Toronto region was 0.02 and $2.3 \%$ among regional individuals and people of Caribbean origin respectively (Chiavetta et al., 1992). HTLV-1 infection was also described in Amerindians from the coastal regions of British Columbia (Dekaban et al., 1994; Picard et al., 1995; Peters et al., 2000). Furthermore, some associated diseases (ATL and TSP/HAM) were reported in coastal British Colombia Indians (Power et al., 1989; Oger et al., 1993; Dekaban et al., 1994; Gascoyne et al., 1996).

In Mexico, there is little information on HTLV-1 prevalence in the general population despite the large population size of this country which counts nearly 115 millions inhabitants. The few studies are mainly conducted in the Yucatan peninsula or some different states (Nuevo Leon in Northeast Mexico) and show the absence of HTLV-1 infection among healthy women as well as in blood donors (Gongora-Biachi et al., 1996, 1997; Trejo-Avila et al., 1996).

\section{Central America}

Central America consists of seven states (Belize, Costa Rica, El Salvador, Guatemala, Honduras, Nicaragua, and Panama). In 2012, its estimated population is 42.6 millions. Despite the fact that some of these countries have strong commercial and cultural ties with the highly HTLV-1 endemic Caribbean Islands, relatively few studies concerning the HTLV-1 infection and the associated diseases 
have been performed except in the Honduras, Panama and, to a lesser extent, in Costa Rica. In these countries, the HTLV-1 seroprevalence is rather low but with significant differences between the populations tested. Thus, the HTLV-1 prevalence is significantly higher in non-Mestizo population, especially individuals living in the coastal cities of Honduras, than in the Mestizo ethnic groups (8.1 versus $0.5 \%$ respectively; de Rivera et al., 1995). Additional studies showed an overall HTLV-1 prevalence of $0.3 \%$ in the general Honduran population who live in central and Northwestern part of the country (Segurado et al., 1997) and a higher HTLV-1 prevalence in black natives individuals, without known risk factors, but originating from cities located on the Atlantic coast (Vallejo et al., 1996). In Panama, HTLV-1 seroprevalence varied from 0.2 to $2 \%$ in the general adult population throughout the country (Reeves et al., 1990). Few ATL or TSP/HAM cases have been reported from Honduran native-born individuals (Temple et al., 1986) and in the Panamanian population (Levine et al., 1989; Gracia et al., 1990).

The situation regarding HTLV-1 in Nicaragua and Costa Rica is poorly known but rare studies revealed similar relatively low HTLV-1 prevalence rates $(0.2-0.7 \%)$, among the Nicaraguan and Costa Rican adult populations (Khabbaz et al., 1990; Qiu et al., 2008). In Belize, Guatemala and El Salvador, no HTLV-1 record about the prevalence of the HTLV-1 infection has been published to our knowledge.

\section{South America}

This area comprises 13 countries including Argentina, Bolivia, Brazil, Chile, Colombia, Ecuador, French Guyana (an overseas region of France), Guyana, Paraguay, Peru, Surinam, Uruguay, and Venezuela. This represents around 400 millions of persons. Numerous studies on HTLV-1 prevalence have been performed in many of these countries, especially in Brazil, Peru, Columbia, Chile, Argentina, and French Guyana. This vast continent represents, as a whole, a major endemic area for HTLV-1 infection and associated diseases. Even more than in other world regions, it is very difficult to appreciate the general HTLV-1 prevalence in a given country, as specific high endemic foci have been frequently reported in several South American countries. This is exemplified in Peru, in some of the Quechua population groups, and also in Columbia (Tumaco area) or in French Guyana (Noir-Marron population), where some specific groups of African origin are highly endemic for HTLV-I infection and associated diseases.

In Peru, a real multiethnic country mainly inhabited by Mestizos and Amerindians, HTLV-1 prevalence in blood donors ranges from 1.2 to $1.7 \%$ depending on the region (Quispe et al., 2009) and from 1.3 to $3.8 \%$ in pregnant women or in the adult general population (Zurita et al., 1997; Sanchez-Palacios et al., 2003; Alarcon et al., 2006). Furthermore several large series of TSP/HAM and ATL have been reported (Gotuzzo et al., 2004; Beltran et al., 2011). However, as noted above, several studies have clearly demonstrated that persons of Amerindians origin (Quechua speaking groups), often living in isolated areas, are highly HTLV-1 endemic (Fujiyoshi et al., 1999; Einsiedel et al., 2010).

In Chile, mainly populated by persons of Spanish ancestry mixed with various Amerindian groups, the situation appears, by certain aspects, roughly similar than in Peru. Indeed, HTLV-1 seems more endemic among indigenous people from isolated Amerindians groups, living in the Andes, or in the most Southern region of the country, than in the general population. Studies indicated an HTLV-1 seroprevalence ranging from 0.7 to $1.9 \%$ in blood donors (Vasquez et al., 1991). Large series of TSP/HAM (more than 200 cases seen before 1991) have been reported in Chilean patients (Cartier et al., 1989, 1992) while ATL were more rarely described (Cabrera et al., 1991).

In Columbia, several studies were focused on Tumaco, a densely populated island of the Pacific lowland recognized as having a very high prevalence of TSP/HAM (Arango et al., 1988; Zaninovic et al., 1988). In the general population of this specific focus (mostly inhabited by persons of African ancestry), the overall prevalence rate of HTLV-1 was $2.8 \%$ and reached $5.3 \%$ in the adults (Trujillo et al., 1992). Other reports indicated the presence of some foci of HTLV-1 infection in different isolated Indian populations (Zaninovic et al., 1994). Several ATL cases have also been described in patients from Columbia (Blank et al., 1993).

In Venezuela, based on the few available data, the HTLV-1 seroprevalence seems quite low. Indeed, it was of $0.2 \%$ in a large series of blood donors from Caracas (Leon et al., 2003). Furthermore, only rare cases of TSP/HAM have been reported (Zabaleta et al., 1994).

In Paraguay, HTLV-1 is rare and seems absent among the Paraguayan general healthy population (Zoulek et al., 1992). In Urugay, the seroprevalence reached $0.75 \%$ among the Urugayan blood donors (Muchinik et al., 1992).

French Guiana has been extensively studied for HTLV-1 infection (Kazanji and Gessain, 2003). In this French overseas region, HTLV-1 is mainly found in the Noir-Marron population, an ethnic group of African ancestry, also present currently in Surinam (Tortevoye et al., 2000, 2005). Indeed, this population is highly endemic for HTLV-1 (Plancoulaine et al., 1998; Carles et al., 2004) and several ATL cases have been reported in this ethnic group (Gerard et al., 1995). HTLV-1 infection and few associated diseases have also been reported in Guyana, and Surinam mainly in the persons of African ancestry (Pouliquen et al., 2004).

The numerous studies performed on blood donors and pregnant women from different areas of Argentina have revealed globally a low or very HTLV-1 seroprevalence, ranging roughly from 0.01 to $0.2 \%$ depending on the type and geographical location of the tested populations (Gastaldello et al., 2004; Trenchi et al., 2007; Berini et al., 2010). Some regions are thus considered as non-endemic (as the central areas) in contrast to the Northeastern provinces of the country (Biglione et al., 2005). In the same line, relatively few cases of TSP/HAM and ATL have been reported in this country (Biglione et al., 2003) ATL cases seems to be only described in individuals of Caucasian origin (Gioseffi et al., 1995; Marin et al., 2002).

Concerning Brazil, the situation is quite different and based on a large amount of solid publications, we can consider without any doubt that this country of more than 200 millions of inhabitants represents one of the largest endemic area for HTLV-1 and associated diseases. Indeed, several hundreds of cases of TSP/HAM, ATL, as well as large series of infective dermatitis cases have been reported in Brazilian patients (de Oliveira et al., 1990; Pombo De Oliveira, 1996; Araujo et al., 1998; Bittencourt et al., 2009). 
Furthermore, several studies performed on large populations of blood donors have found an heterogeneous HTLV-1 seroprevalence ranging from 0.04 to $1 \%$ depending on the geographical location. The prevalence was higher in the North and Northeast than in the South (Catalan-Soares et al., 2005). Another more recent and large study show Brazilian blood donors prevalence of HTLV1 on the order of one per 1,000 with regional differences probably due to the ethnic origin of the underlying population with indeed a higher prevalence in donors with black skin color $(2.14 / 1,000)$ versus mixed $(1.58 / 1,000)$ or white $(0.79 / 1,000$; Carneiro-Proietti et al., 2012). Similarly, HTLV-1 prevalence in pregnant women ranges from 0.1 to $0.8 \%$ depending on the tested area (Bittencourt et al., 2001; Olbrich Neto and Meira, 2004; Figueiro-Filho et al., 2007; Ydy et al., 2009; Guimaraes de Souza et al., 2012). Interestingly, Salvador de Bahia, a large city of the eastern part of the country, with a majority of inhabitants of African ancestry, is considered as the Brazilian city with the highest global HTLV-1 prevalence (around 1.3\% of blood donors, and $1.8 \%$ in the general population; Galvao-Castro et al., 1997; Dourado et al., 2003).

\section{HTLV-1 IN THE CARIBBEAN REGION}

This region comprises more than 7,000 islands organized into 30 territories including sovereign states (e.g., Cuba, Jamaica, Haiti and Dominican Republic), overseas departments (e.g., Martinique, Guadeloupe) and dependencies (e.g., Bermuda, Caiman Islands), totalizing around 40 millions of inhabitants. The majority of these islands have a relatively small population (few thousands to half million persons). Only Cuba, Haiti/Dominican Republic, and Jamaica have a population of more than two millions. All the islands, which are mainly peopled with persons of African ancestry, represent a high endemic region for HTLV-1 infection and associated diseases.

Jamaica has been extensively studied concerning HTLV-1 infection (Clark et al., 1985; Murphy et al., 1991). Large series of ATL, TSP/HAM, and infective dermatitis have been reported in this island and in immigrants from Jamaica living, especially, in the United Kingdom (Gibbs et al., 1984; Rodgers-Johnson et al., 1988; Mowbray et al., 1989; La Grenade et al., 1990). In a large cohort of 13,260 Jamaicans from all parts of the island, HTLV-1 seroprevalence was high (mean $6.1 \%$ ) ranging from 1.7 to $17.4 \%$, depending on sex and age (Murphy et al., 1991). In pregnant women and in blood donors, it was of around 2-3.8\% (Wiktor et al., 1993; Dowe et al., 1998; Brady-West and Buchner, 2000; Maloney et al., 2006). The situation is less known but could be quite similar in Haiti and the Dominican Republic. HTLV-1 seroprevalence in pregnant women is around 2.2-4.2\% (Allain et al., 1992; Tortevoye et al., 2005) and it is around of 3.8-4.3\% in rural Haitian populations (Schill et al., 1989; Grant et al., 1992). Furthermore, some series of ATL and TSP/HAM have been reported mainly in immigrants from this island living in France and the US (Vernant et al., 1987; Bhagavati et al., 1988; Gout et al., 1989; Gessain et al., 1990a; Besson et al., 2001). In the French West Indies (FWI: Martinique and Guadeloupe), HTLV-1 seroprevalence in blood donors is around 0.3-0.4\% (Cesaire et al., 1999; Rouet et al., 1999a,b) and in pregnant women from Martinique it is of around 2\% (Denis et al., 1988; Mansuy et al., 1999). Furthermore, few hundreds of TSP/HAM and of ATL have been reported during the last 25 years in these islands (Vernant et al., 1987; Plumelle et al., 1993) and in immigrants in Metropolitan France (Gout et al., 1989; Gessain et al., 1990a,c; Besson et al., 2001). HTLV-1 is also endemic at a similar level in Trinidad and Tobago (Blattner et al., 1990; Daisley et al., 1991) as well as in Barbados (Riedel et al., 1989).

In contrast, the studies performed in Cuba indicated that HTLV-1 seroprevalence is very low in this island (Hernandez Ramirez et al., 1991; Silva Cabrera et al., 1997) with also only very few ATL or TSP/HAM cases reported (Estrada et al., 1995). This is very probably linked, partly, to the different ethnic background of the islands with relatively few persons of African ancestry in Cuba as compared to Jamaica, Haiti, or the French West Indies. The estimates of the number of HTLV-1 infected persons for some islands in the Caribbean are given in Table 2.

\section{HTLV-1 IN ASIA}

Asia is the world's largest and most populous continent with nearly 3.9 billion people ( $60 \%$ of the world's current human population). Here we arbitrarily defined four subregions: (1) East Asia (China, Japan, North and South Korea, Mongolia, and Taiwan), (2) North (Siberia), Central (Afghanistan, Iran, Kazakhstan, Kyrgyzstan, Turkmenistan, and Uzbekistan,) and Southwest Asia (Arabian Peninsula, Armenia, Georgia, Israel, Jordan, Lebanon, Syria, and Turkey), (3) South Asia (Bangladesh, Bhutan, India, Nepal, Pakistan, and Sri Lanka,) and (4) Southeast Asia (Brunei, Burma, Cambodia, Indonesia, Laos, Malaysia, Philippines, Singapore, Thailand, East Timor, and Vietnam). Except for some very important endemic foci including mainly Japan and Iran, the prevalence of HTLV-1 and associated diseases in Asia seems very low. However, in most of the areas, due to the lack of large and representative studies, the situation remains still poorly known.

\section{East Asia}

East Asia comprises more than 1.4 billion people (about $20 \%$ of the world population). In Mainland China, no general populationbased-study has been performed to our knowledge regarding HTLV-1 prevalence. However, a large-scale study concerning 145,293 blood donors representative of 13 provinces revealed a very low global prevalence $(0.013 \%$; Wang et al., 2005). Interestingly, all HTLV-1 seropositive individuals originate from the Fujian province in the Southeast and the prevalence rate in this peculiar province reached $0.055 \%$. This confirmed the prevalence rate $(0.06 \%)$ previously found in the same province among healthy individuals (Wang et al., 2004). Concerning the HTLV-1 related diseases, while very few cases of TSP/HAM have been reported (Seyfert et al., 2004), some series of ATL cases were found in Chinese patients (Zhuo et al., 1995; Au and Lo, 2005). These ATL cases were mainly distributed in patients from the coastal provinces and the Southeast China especially in the Fujian province.

In Japan, HTLV-1 infection has been extensively studied for more than 30 years. Japan is one of the most important foci of HTLV-1 infection and associated diseases (Watanabe, 2011). Indeed, around 1,000 of ATL cases are diagnosed each year (Tajima, 1990) and several hundreds of TSP/HAM have been reported (Osame et al., 1990), as well as large series of other HTLV-1 associated diseases including uveitis (Mochizuki et al., 1992). The minimal global prevalence of HTLV-1 infection in Japan as determined 
by screening of blood donors is estimated to be at least 1.08 million in 2006 (Satake et al., 2012). Based on a previous nationwide survey, performed also among blood donors, the number of HTLV-1 infected individuals was around 1.2 million (Tajima, 1990). For several reasons, the prevalence calculated from blood donors survey is very probably lower than the actual value (Satake et al., 2012). Thus, Japan comprises very probably the largest HTLV-1 carriers number in the world. Since the first studies, the repartition of HTLV-1 carriers in Japan is quite uneven with prevalence rates among blood donors varying from $1 \%$ in Hokkaido to more than 6\% in Kyushu and Okinawa Islands in the Southern part of the archipelago (Hinuma et al., 1982; Maeda et al., 1984; Tajima, 1990). Several studies in pregnant women also revealed such a heterogeneous situation, which origin remains to be determined, with an HTLV-1 prevalence ranging from 0.5\% (in North/central Japan) to $5.8 \%$ (Southern part of the country; Oki et al., 1992; Umemoto et al., 1994; Goto et al., 1997; Maehama, 2004). In some villages or towns of highly endemic areas, HTLV-1 prevalence can reach $30-40 \%$ in adults, aged more than 50 years old (Kohakura et al., 1986; Tajima et al., 1987). Several programs aimed to prevent HTLV-1 transmission from mother to child, by refraining HTLV-1 infected mothers to breast-fed their children, have been implemented with great success (Hino, 2011). Although the HTLV-1 prevalence in Japan is very high, it is not clear why neighboring regions such as East China or Korea have a low prevalence. Indeed, the studies among Korean blood donors from various districts of Korea revealed very low HTLV-1 seropositive rates (0.007-0.25\%; Lee et al., 1986; Kim et al., 1999; Kwon et al., 2008). Furthermore, very few cases of ATL and TSP/HAM have been reported in Korean patients (Park et al., 1991; Saito et al., 1993; Jeon et al., 2000).

In Taiwan, slightly more data are available and the prevalence of HTLV-1 infection seems higher. HTLV-1 screening in six blood centers revealed indeed an HTLV-1 seropositivity rate of $0.058 \%$ (Lu et al., 2001). Furthermore, in the Taiwanese adult population, aged more than 30 years, the HTLV-1 prevalence varies from 0.82 to $1.63 \%$ according to the districts investigated (Chen et al., 1999). Lastly, series of ATL cases have been diagnosed in Taipei (Lee et al., 2010).

\section{North, Central, and Southwest Asia}

Sporadic HTLV-1 infection cases have been detected in various small ethnic populations of Northern and Eastern Siberia, especially among individuals from the Nivikhi group (Seniuta et al., 1990; Gessain and de The, 1996). These data suggest the possible existence of HTLV-1 foci, which makes impossible a global estimation of the HTLV-1 prevalence in these vast regions. In Central Asia, Iran is by far the most studied country, especially the area of Mashad in the Northeast of the country. According to the type of studies and of tested populations, HTLV-1 prevalence is estimated to range from 0.77 to $3 \%$ in adults (Safai et al., 1996; Abbaszadegan et al., 2003; Rafatpanah et al., 2011). A more recent study indicates an HTLV-1 prevalence of $1.66 \%$ in adults from the city of Sabzevar located in the Southeast of Mashad and confirmed that HTLV-1 is highly endemic in this region (Azarpazhooh et al., 2012). Furthermore, relatively large series of ATL as well as TSP/HAM cases originating from the Mashad region are reported in Iran (Sidi et al., 1990; Kchour et al., 2009) but also in Iranian immigrants living in European countries, the United States, or Israël (Sidi et al., 1990; Gabarre et al., 1993; Miller et al., 1998). No data are available from other areas of central Asia except scarce findings from Turkmenistan where the HTLV-1 seroprevalence rate among blood donors reached 0.2\% (3/1,510; Senyuta et al., 1998).

In Southwest Asia, the HTLV-1 infection appeared to be nonendemic. In Saudi Arabia, there is no case of HTLV-1 infection or extremely low HTLV-1 seroprevalence rates (0.002-0.0052\%) reported among blood donors (Bernvil et al., 1997; Arif and Ramia, 1998; El-Hazmi, 2004). The situation is quite comparable in other Persian Gulf countries such as Kuwait where the HTLV1 seroprevalence observed among blood donors reached $0.009 \%$ (Al-Mufti et al., 1997). Nevertheless, few symptomatic HTLV-1 cases have been described in this latter country (Voevodin et al., 1995) and Iraq (Denic et al., 1990).

In Israel, an immigration state, studies indicated that most of infected persons originated from highly endemic countries (Iran, Romania, and Africa). Thus, the HTLV-1 prevalence must be appreciated according to the donors' countries of origin. However, the HTLV-1 prevalence in blood donors born in Israel reached 0.001\% (Stienlauf et al., 2009). Furthermore, some ATL and TSP/HAM cases have been described mainly among immigrants of Romanian or Iranian origin (Sidi et al., 1990; Shtalrid et al., 2005).

In Lebanon, none of 1,900 blood donors screened was seropositive for HTLV-1 (Naman et al., 2002) although one ATL case of Lebanese origin has been described (Bitar et al., 2009). Quite comparable situation is observed in Turkey where none among 10,000 Healthy blood donors was HTLV-1 seroreactive (Sertoz et al., 2010). No data are available, to our knowledge, concerning the HTLV-1 situation in Jordan, Syria, and Armenia.

\section{South Asia}

India is with China, the second most populated country in the world with 1.2 billion inhabitants. If we consider neighboring countries such as Pakistan, Bangladesh, Sri lanka, and Nepal plus Bhutan and Maldives territories, the South Asian population reached 1.6 billion (a quarter of the world population). In this region, the studies concerning HTLV-1 prevalence are scarce and the most recent one among Indian blood donors revealed a $0.14 \%$ prevalence rate (Kumar and Gupta, 2006). Other study demonstrated no serological evidence of HTLV-1 infection among the pregnant women tested (Ramalingam et al., 2001). Despite the low HTLV-1 prevalence rate, some ATL, and TSP/HAM cases have been regularly reported especially in Southern India (Andhra Pradesh, Kerala, and Tamil Nadu; Chandy et al., 1991; Babu et al., 1993; Jain et al., 2008; Ahmed et al., 2012) and Western India (Singhal et al., 1993). Thus, the prevalence of HTLV-1 carriers in India seems rare but taken into account the huge population size, large-scale studies are necessary to assess the global prevalence rate before to conclude that this infection is a minor public health hazard and to estimate a reliable HTLV-1 prevalence rate.

In Bangladesh, despite the large population size, no HTLV-1 prevalence study has been performed. A sporadic occurrence of HTLV-1 infection (0.9\%) was found among patients with motor neuron disease called neurolathyrism (Haque et al., 1994). In Pakistan, who shares with Bangladesh the same population size, no 
data concerning HTLV-1 prevalence is available. This situation is quite the same in others South Asian territories such as Nepal, Sri Lanka, Bhutan, and Maldives archipelago where HTLV-1 infection has never been investigated to our knowledge.

\section{Southeast Asia}

The Southeast Asian region comprises more than half a billion individuals. However, the situation regarding the HTLV-1 prevalence in the most populated countries has been poorly described. In Indonesia, the few studies revealed no HTLV-1 carrier among the blood donors tested (Tanggo et al., 2000). In Philippines, anecdotal, and ancient study suggested that the infection is present in the general population (Ishida et al., 1988). In the neighboring countries such as Malaysia, Vietnam, Cambodia, Laos, and Burma, no reliable information is available concerning the HTLV1 global epidemiology. Moreover, no evidence of HTLV-1 infection among Hmong individuals from Northern Thailand was reported (Louisiriotchanakul et al., 2000) and a study performed on Hmong refugees living in French Guyana confirmed this data (Tortevoye et al., 2000). The situation seems quite different in the eastern part of New Guinea Island called Irian Jaya, where sporadic cases of HTLV-1 infection have been reported in some small isolated tribes (Re et al., 1989). Despite the lack of population-based studies in the Southeast Asian populations, the HTLV-1 prevalence rate seems to be low.

\section{HTLV-1 IN OCEANIA}

Oceania is a vast zone between continental Asia and the Americas comprising mostly coral atolls and volcanic islands. It is divided into three subregions, Micronesia (Kiribati, Marshall Islands, and Nauru), Australo-Melanesia (Australia, Fiji Islands, New Caledonia, Papua New Guinea, Solomon Islands, and Vanuatu), and Polynesia (American Samoa, Cook Islands, Easter Island, French Polynesia, Hawaii, New Zealand, Samoa, Tonga, Tuvalu, Wallis, and Futuna). The population is around 35 millions individuals with two third of Australian origin.

\section{Australo-Melanesia}

Only few population-based-study using solid serological confirmation criteria have been performed regarding HTLV-1 prevalence in the Australo-Melanesian region. Interestingly, few studies, conducted among Papuan aboriginal populations, demonstrated that some remote tribes as the Hagahai population living in the highlands (Madang province), exhibited higher HTLV-1 prevalence rate than population groups originating from different Papuan provinces such as the Sepik province (Yanagihara et al., 1990; Sanders et al., 1993; Yamaguchi et al., 1993; Takao et al., 2000). In the Solomon Islands, the HTLV-1 seroprevalence rate range from 1.2 to $3 \%$ according to the populations (hospitalized individuals, blood donors) and the islands investigated (Yanagihara et al., 1991; Nicholson et al., 1992; Furusyo et al., 1999). In Vanuatu archipelago, a large-scale population-based-study $(4,247$ individuals mostly adults) showed that the HTLV-1 prevalence rate was of $0.62 \%$ (Cassar et al., 2007). In Fiji and New Caledonia archipelagoes, no HTLV-1 infection was brought out by the very few studies performed among the native-born populations tested (Louis et al., 1990; Nicholson et al., 1992; Chungue et al., 1993).
In Australia, the situation for HTLV-1 is quite different as we considered Aboriginal populations from Central Australia or blood donors comprising mainly white non-Aboriginal individuals living in coastal areas. Thus, the studies conducted among blood donors from main Australian cities (Adelaide, Brisbane, Melbourne, Perth, and Sydney) revealed that HTLV-1 prevalence rate is very low, comprised between 0.001 and $0.032 \%$ (Whyte, 1997; Polizzotto et al., 2008). In contrast, several studies indicated that the Aboriginal groups of inland Australian regions represent a high HTLV-1 endemic population (May et al., 1988; Einsiedel et al., 2010, 2012). Moreover, HTLV-1 related cases, ATL and/or TSP/HAM, have been described among the Aboriginal communities of central Australia (Kirkland et al., 1991; Rajabalendaran et al., 1993), Papua New Guinea (Yanagihara et al., 1990), and the Solomon Islands (Ajdukiewicz et al., 1989).

\section{Polynesia/Micronesia}

The few reliable studies performed in Polynesia/Micronesia regarding the HTLV-1 prevalence among native-born Polynesian individuals, indicated that the infection is absent or very rare (Nicholson et al., 1992; Chungue et al., 1993; Ohkura et al., 1999). In the Hawaiian archipelago, the virus is present but the studies suggested that HTLV-1 was introduced with the Japanese immigration (Kimata et al., 1989). Indeed, ATL and TSP/HAM cases were observed among immigrants from Southern Japan and their descendants (Yim et al., 1986; Yanagihara et al., 1989; Dixon et al., 1990). Few other studies have described the HTLV-1 situation in the Cook Islands, Kiribati, New Zealand, the Samoa and Wallis, and Futuna, but no HTLV1 seropositive case has been documented to date (Reddy et al., 1987; Louis et al., 1990; Nicholson et al., 1992; Chungue et al., 1993).

\section{CONCLUSION}

Our best estimates range approximately from 5 to 10 millions HTLV-1 infected individuals. However, these results were only based on nearly 1.5 billion of individuals originating from known HTLV-1 endemic areas with reliable available epidemiological data. Correct estimates in other highly populated regions, such as China, India, the Maghreb, and East Africa, is currently not possible. The real number of HTLV-1 carriers is thus very probably much higher.

\section{ACKNOWLEDGMENTS}

The authors would like to thank Pr. E. Murphy from University of California, San Francisco, California, USA, and B. Usadi from University of California, Berkeley School of Public Health, California, USA, for fruitful discussions concerning the estimation of HTLV-1 carriers in the USA, Jamaica and Brazil. The authors are grateful to Pr. PE. Ceccaldi from Université Paris Diderot, Sorbonne Paris Cité, Cellule Pasteur, Paris, France, for the critical review of this manuscript. Financial support: This study has received funding from the French Government's Investissement d'Avenir Program, Laboratoire d'Excellence "Integrative Biology of Emerging Infectious Diseases" (Grant no. ANR-10-LABX-62IBEID). 


\section{REFERENCES}

Abbaszadegan, M. R., Gholamin, M., Tabatabaee, A., Farid, R., Houshmand, M., and Abbaszadegan, M. (2003). Prevalence of human T-lymphotropic virus type 1 among blood donors from Mashhad, Iran. J. Clin. Microbiol. 41, 2593-2595.

Ades, A. E., Parker, S., Walker, J., Edginton, M., Taylor, G. P., and Weber, J. N. (2000). Human T cell leukaemia/lymphoma virus infection in pregnant women in the United Kingdom: population study. BMJ 320, 1497-1501.

Ahmed, F., Murthy, S. S., Mohan, M. V., and Rajappa, S. J. (2012). HTLV 1 associated adult $\mathrm{T}$ cell lymphoma/leukemia a clinicopathologic, immunophenotypic tale of three cases from non-endemic region of south India. Indian J. Pathol. Microbiol. 55, 92-96.

Ajdukiewicz, A., Yanagihara, R., Garruto, R. M., Gajdusek, D. C., and Alexander, S. S. (1989). HTLV-1 myeloneuropathy in the Solomon Islands. N. Engl. J. Med. 321, 615-616.

Alarcon, J. O., Friedman, H. B., Montano, S. M., Zunt, J. R., Holmes, K. K., and Quinnan, G. V. Jr. (2006). High endemicity of human T-cell lymphotropic virus type 1 among pregnant women in peru. J. Acquir. Immune Defic. Syndr. 42, 604-609.

Allain, J. P., Hodges, W., Einstein, M. H., Geisler, J., Neilly, C., Delaney, S., et al. (1992). Antibody to HIV-1, HTLV-I, and HCV in three populations of rural Haitians. J. Acquir. Immune Defic. Syndr. 5, 1230-1236.

Al-Mufti, S., Voevodin, A., Ahmed, S., Al-Hamdan, S., and Al-Bisher, A. A. (1997). Prevalence of human Tcell lymphotropic virus type I infection among volunteer blood donors in Kuwait. J. Acquir. Immune Defic. Syndr. Hum. Retrovirol. 15, 88-90.

Ampofo, W., Nii-Trebi, N., Ansah, J., Abe, K., Naito, H., Aidoo, S., et al. (2002). Prevalence of blood-borne infectious diseases in blood donors in Ghana. J. Clin. Microbiol. 40, 3523-3525.

Analo, H. I., Akanmu, A. S., Akinsete, I., Njoku, O. S., and Okany, C. C. (1998). Seroprevalence study of HTLV-1 and HIV infection in blood donors and patients with lymphoid malignancies in Lagos, Nigeria. Cent. Afr. J. Med. 44, 130-134.

Andersson, S., Dias, F., Mendez, P. J., Rodrigues, A., and Biberfeld, G. (1997). HTLV-I and -II infections in a nationwide survey of pregnant women in Guinea-Bissau, West
Africa. J. Acquir. Immune Defic. Syndr. Hum. Retrovirol. 15, 320-322.

Ando, Y., Nakano, S., Saito, K., Shimamoto, I., Ichijo, M., Toyama, T., et al. (1987). Transmission of adult T-cell leukemia retrovirus (HTLV-I) from mother to child: comparison of bottle- with breast-fed babies. Jpn. J. Cancer Res. 78, 322-324.

Arango, C., Concha, M., Zaninovic, V., Corral, R., Biojo, R., Borrero, I., et al. (1988). Epidemiology of tropical spastic paraparesis in Columbia and associated HTLV-I infection. Ann. Neurol. 23(Suppl.), S161-S165.

Araujo, A. Q., Andrade-Filho, A. S., Castro-Costa, C. M., MennaBarreto, M., and Almeida, S. M. (1998). HTLV-I-associated myelopathy/tropical spastic paraparesis in Brazil: a nationwide survey. HAM/TSP Brazilian Study Group. J. Acquir. Immune Defic. Syndr. Hum. Retrovirol. 19, 536-541.

Arif, M., and Ramia, S. (1998). Seroprevalence of human Tlymphotropic virus type I (HTLV-I) in Saudi Arabia. Ann. Trop. Med. Parasitol. 92, 305-309.

Armah, H. B., Narter-Olaga, E. G., Adjei, A. A., Asomaning, K., Gyasi, R. K., and Tettey, Y. (2006). Seroprevalence of human T-cell lymphotropic virus type I among pregnant women in Accra, Ghana. J. Med. Microbiol. 55, 765-770.

Au, W. Y., and Lo, J. Y. (2005). HTLV-1-related lymphoma in Hong Kong Chinese. Am. J. Hematol. 78, 80-81.

Azarpazhooh, M. R., Hasanpour, K., Ghanbari, M., Rezaee, S. A., Mashkani, B., HedayatiMoghaddam, M. R., et al. (2012). Human T-lymphotropic virus type 1 prevalence in northeastern Iran, Sabzevar: an epidemiologic-based study and phylogenetic Analysis. AIDS Res. Hum. Retroviruses 28, 1095-1101.

Babu, P. G., Gnanamuthu, C., Saraswathi, N. K., Nerurkar, V. R., Yanagihara, R., and John, T. J. (1993). HTLV-I-associated myelopathy in south India. AIDS Res. Hum. Retroviruses 9, 499-500.

Becker, W. B., Becker, M. L., Homma, T., Brede, H. D., and Kurth, R. (1985). Serum antibodies to human T-cell leukaemia virus type I in different ethnic groups and in non-human primates in South Africa. S. Afr. Med. J. 67, 445-449.

Beltran, B., Quinones, P., Morales, D., Cotrina, E., and Castillo, J. J. (2011). Different prognostic factors for survival in acute and lymphomatous adult T-cell leukemia/lymphoma. Leuk. Res. 35, 334-339.

Berini, C. A., Gendler, S. A., Pascuccio, S., Eirin, M. E., McFarland, W., Page, K., et al. (2010). Decreasing trends in HTLV-1/2 but stable HIV-1 infection among replacement donors in Argentina. J. Med. Virol. 82, 873-877.

Bernvil, S. S., Andrews, V., and Coulter, N. (1997). International forum: Saudi Arabia. Donor screening for HTLV-I in Saudi Arabia: is it cost effective? Transfus. Sci. 18, 45-47.

Bertherat, E., Makuwa, M., Renaut, A., Nabias, R., and Georges-Courbot, M. C. (1998). HIV-1, HTLV-I, and HTLV-II in a semiurban population in East Gabon. J. Acquir. Immune Defic. Syndr. Hum. Retrovirol. 19, 430-432.

Besson, C., Gonin, C., Brebion, A. Delaunay, C., Panelatti, G., and Plumelle, Y. (2001). Incidence of hematological malignancies in Martinique, French West Indies, overrepresentation of multiple myeloma and adult $\mathrm{T}$ cell leukemia/lymphoma. Leukemia 15, 828-831.

Bhagavati, S., Ehrlich, G., Kula, R. W., Kwok, S., Sninsky, J., Udani, V., et al. (1988). Detection of human Tcell lymphoma/leukemia virus type I DNA and antigen in spinal fluid and blood of patients with chronic progressive myelopathy. N. Engl. J. Med. 318, 1141-1147.

Bhatt, N. B., Gudo, E. S., Sema, C. Bila, D., Di Mattei, P., Augusto, O., et al. (2009). Loss of correlation between HIV viral load and CD4+ T-cell counts in HIV/HTLV1 co-infection in treatment naive Mozambican patients. Int. J. STD AIDS 20, 863-868.

Bhigjee, A. I., Kelbe, C., Haribhai, H. C., Windsor, I. M., Hoffmann, M. H., Modi, G., et al. (1990). Myelopathy associated with human $\mathrm{T}$ cell lymphotropic virus type I (HTLV-I) in natal, South Africa. A clinical and investigative study in 24 patients. Brain $113(\mathrm{Pt} 5)$, 1307-1320.

Bhigjee, A. I., Thaler, D., Madurai, S., Gouws, E., and Bill, P. L. (1994). Seroprevalence of HTLV-I in Natal/KwaZulu. S. Afr. Med. J. 84, 368.

Bhigjee, A. I., Vinsen, C., Windsor, I. M., Gouws, E., Bill, P. L., and Tait, D. (1993). Prevalence and transmission of HTLV-I infection in Natal/KwaZulu. S. Afr. Med. J. 83, 665-667.

Biggar, R. J., Neequaye, J. E., Neequaye, A. R., Ankra-Badu, G. A.,
Levine, P. H., Manns, A., et al. (1993). The prevalence of antibodies to the human $\mathrm{T}$ lymphotropic virus (HTLV) in Ghana, West Africa. AIDS Res. Hum. Retroviruses 9, 505-511.

Biggar, R. J., Saxinger, C., Gardiner, C. Collins, W. E., Levine, P. H., Clark, J. W., et al. (1984). Type-I HTLV antibody in urban and rural Ghana, West Africa. Int. J. Cancer 34, 215-219.

Biglione, M. M., Astarloa, L., and Salomon, H. E. (2005). High prevalence of HTLV-I and HTLV-II among blood donors in Argentina: a South American health concern. AIDS Res. Hum. Retroviruses 21, 1-4.

Biglione, M. M., Pizarro, M., Puca, A., Salomon, H. E., and Berria, M. I. (2003). A cluster of human T-cell lymphotropic virus type I-associated myelopathy/tropical spastic paraparesis in Jujuy, Argentina. J. Acquir. Immune Defic. Syndr. 32, 441-445.

Bitar, N., Hajj, H. E., Houmani, Z. Sabbah, A., Otrock, Z. K., Mahfouz, R., et al. (2009). Adult Tcell leukemia/lymphoma in the Middle East: first report of two cases from Lebanon. Transfusion 49, 1859-1864.

Bittencourt, A. L., Barbosa, H. S., Vieira, M. D., and Farre, L. (2009). Adult Tcell leukemia/lymphoma (ATL) presenting in the skin: clinical, histological and immunohistochemical features of 52 cases. Acta Oncol. 48, 598-604.

Bittencourt, A. L., Dourado, I., Filho, P. B., Santos, M., Valadao, E., Alcantara, L. C., et al. (2001). Human T-cell lymphotropic virus type 1 infection among pregnant women in northeastern Brazil. J. Acquir. Immune Defic. Syndr. 26, 490-494

Blakeslee, J. R. Jr., McClure, H. M., Anderson, D. C., Bauer, R. M., Huff, L. Y., and Olsen, R. G. (1987). Chronic fatal disease in gorillas seropositive for simian $\mathrm{T}$ lymphotropic virus I antibodies. Cancer Lett. 37, 1-6.

Blank, A., Yamaguchi, K., Blank, M., Zaninovic, V., Sonoda, S., and Takatsuki, K. (1993). Six Colombian patients with adult T-cell leukemia/lymphoma. Leuk. Lymphoma 9, 407-412.

Blattner, W. A., Nomura, A., Clark, J. W., Ho, G. Y., Nakao, Y., Gallo, R., et al. (1986). Modes of transmission and evidence for viral latency from studies of human T-cell lymphotrophic virus type I in Japanese migrant populations in Hawaii. Proc. Natl. Acad. Sci. U.S.A. 83, 4895-4898. 
Blattner, W. A., Saxinger, C., Riedel, D., Hull, B., Taylor, G., Cleghorn, F., et al. (1990). A study of HTLV-I and its associated risk factors in Trinidad and Tobago. J. Acquir. Immune Defic. Syndr. 3, 1102-1108.

Blayney, D. W., Jaffe, E. S., Blattner, W. A., Cossman, J., Robert-Guroff, M., Longo, D. L., et al. (1983). The human T-cell leukemia/lymphoma virus associated with American adult T-cell leukemia/lymphoma. Blood 62, 401-405.

Brady-West, D. C., and Buchner, L. M. (2000). Retrospective audit of blood donation at a hospital-based blood centre. Implications for blood product supply and safety. West Indian Med. J. 49, 226-228.

Brant, L. J., Cawley, C., Davison, K. L., and Taylor, G. P. (2011). Recruiting individuals into the HTLV cohort study in the United Kingdom: clinical findings and challenges in the first six years, 2003 to 2009. Euro Surveill. 16, pii $=20017$.

Cabrera, M. E., Gray, A. M., Cartier, L., Araya, F., Hirsh, T., Ford, A. M., et al. (1991). Simultaneous adult T-cell leukemia/lymphoma and sub-acute polyneuropathy in a patient from Chile. Leukemia 5, 350-353.

Calderon, E. J., Rey, C., Medrano, F. J., Sanchez-Roman, J., Soriano, V., Torres, Y., et al. (1995). Prevalence of infection by human T-cell leukemia virus types I and II in southern Spain. Eur. J. Clin. Microbiol. Infect. Dis. 14, 686-690.

Cantor, K. P., Weiss, S. H., Goedert, J. J., and Battjes, R. J. (1991). HTLVI/II seroprevalence and HIV/HTLV coinfection among U.S. intravenous drug users. J. Acquir. Immune Defic. Syndr. 4, 460-467.

Carles, G., Tortevoye, P., Tuppin, P., Ureta-Vidal, A., Peneau, C., El Guindi, W., et al. (2004). HTLV1 infection and pregnancy. J. Gynecol. Obstet. Biol. Reprod. (Paris) 33, 14-20.

Carneiro-Proietti, A. B., Sabino, E. C., Leao, S., Salles, N. A., Loureiro, P., Sarr, M., et al. (2012). Human Tlymphotropic virus type 1 and type 2 seroprevalence, incidence, and residual transfusion risk among blood donors in Brazil during 2007-2009. AIDS Res. Hum. Retroviruses 28, 1265-1272.

Cartier, L., Araya, F., Castillo, J. L., Ruiz, F., Gormaz, A., and Tajima, K. (1992). Progressive spastic paraparesis associated with human T-cell leukemia virus type I (HTLV-I). Intern. Med. 31, 1257-1261.
Cartier, L., Mora, C., Araya, F., Castillo, J., Verdugo, R., and Miller, M. (1989). HTLV-I positive spastic paraparesis in a temperate zone. Lancet 1, 556 .

Cassar, O., Capuano, C., Bassot, S., Charavay, F., Duprez, R., Afonso, P. V., et al. (2007). Human T lymphotropic virus type 1 subtype C melanesian genetic variants of the Vanuatu Archipelago and Solomon Islands share a common ancestor. J. Infect. Dis. 196, 510-521.

Catalan-Soares, B., Carneiro-Proietti, A. B., and Proietti, F. A. (2005) Heterogeneous geographic distribution of human T-cell lymphotropic viruses I and II (HTLV-I/II): serological screening prevalence rates in blood donors from large urban areas in Brazil. Cad. Saude Publica 21, 926-931.

Caterino-de-Araujo, A., Magri, M. C., Costa, E. A., and Manuel, R. C. (2010). Prevalence of human Tcell lymphotropic virus (HTLV-1/2) in individuals from public health centers in Mozambique. AIDS Res. Hum. Retroviruses 26, 559-561.

Catovsky, D., Greaves, M. F., Rose, M., Galton, D. A., Goolden, A. W., McCluskey, D. R., et al. (1982). Adult T-cell lymphoma-leukaemia in Blacks from the West Indies. Lancet 1, 639-643.

Ceesay, M. M., Matutes, E., Taylor, G. P., Fields, P., Cavenagh, J., Simpson, S., et al. (2012). Phase II study on combination therapy with CHOPZenapax for HTLV-I associated adult T-cell leukaemia/lymphoma (ATLL). Leuk. Res. 36, 857-861.

Cesaire, R., Bera, O., Maier, H., Lezin, A., Martial, J., Ouka, M., et al. (1999). Seroin determinate patterns and seroconversions to human $\mathrm{T}$ lymphotropic virus type I positivity in blood donors from Martinique, French West Indies. Transfusion 39, 1145-1149.

Chandy, M., Babu, P. G., Saraswathy, N. K., Ishida, T., and John, T. J. (1991). HTLV-1 infection in patients with leukaemia in southern India. Lancet 338, 380-381.

Chavance, M., Frery, N., Valette, I., Monplaisir, N., and Schaffar, L. (1989). Cohort effect of HTLV-I seroprevalence in southern Japan. Lancet 2, 1337.

Chen, Y. M., Ting, S. T., Lee, C. M., Liu, W. T., Pan, W. H., Cheng, A. T., et al. (1999). Community-based molecular epidemiology of HTLV type I in Taiwan and Kinmen: implication of the origin of the cosmopolitan subtype in northeast Asia. AIDS Res. Hum. Retroviruses 15, 229-237.
Chiavetta, J., Nusbacher, J., Tam, F., Wall, A., Steaffens, J., and Lee, H. (1992). Prevalence of antibody to human T-cell lymphotropic virus type I/II in people of Caribbean origin in Toronto. CMAJ 147, 1493-1498.

Chironna, M., Calabro, M. L., Quarto, M., Germinario, C., Fiore, J. R., Favero, A., et al. (1996). HTLV-I and HTLV-II infections in subjects at risk for HIV-I infection from southeastern Italy (Apulia region). Int. J. Cancer 65, 746-750.

Chungue, E., Boutin, J. P., Le Marchand, L., Philippon, G., Le Guellec A., Chanteau, S., et al. (1993). Seroepidemiological survey of HTLV-I infection in French Polynesia, Cook Islands and Fiji. Eur. J. Epidemiol. 9, 347-350.

Clark, J., Saxinger, C., Gibbs, W. N. Lofters, W., Lagranade, L., Deceulaer, K., et al. (1985). Seroepidemiologic studies of human $\mathrm{T}$ cell leukemia/lymphoma virus type I in Jamaica. Int. J. Cancer 36, 37-41.

Cnudde, F., Gessain, A., Dandelot, J. B., Carlier, P., Julvez, J., Andriambao, P. S., et al. (1991). HTLVI in neurological patients from some Indian Ocean islands. J. Acquir. Immune Defic. Syndr. 4 734-735.

Collenberg, E., Ouedraogo, T., Ganame, J., Fickenscher, H., Kynast-Wolf, G., Becher, H., et al. (2006). Seroprevalence of six different viruses among pregnant women and blood donors in rural and urban Burkina Faso: a comparative analysis. J. Med. Virol. 78, 683-692.

Courouce, A. M., Pillonel, J., Lemaire, J. M., Maniez, M., and Brunet, J. B. (1993). Seroepidemiology of HTLV-I/II in universal screening of blood donations in France. AIDS 7, 841-847.

Courtois, F., Barin, F., Larsen, M. Brossard, Y., Masselin, A., and Engelman, P. (1990). HTLV-I/II infection in pregnant women in Paris. Lancet 335,1103 .

Cunha, L., Plouzeau, C., Ingrand, P., Gudo, J. P., Ingrand, I., Mondlane, J., et al. (2007). Use of replacement blood donors to study the epidemiology of major blood-borne viruses in the general population of Maputo, Mozambique. J. Med. Virol. 79, 1832-1840.

da Silva, Z. J., Nielsen, J., Andersen, A., Oliveira, I., Dias, F., Rodrigues, A., et al. (2009). Decline in human Tcell lymphotropic virus-1 prevalence in urban areas of Bissau, GuineaBissau: exploring the association with HIV infections. AIDS 23, 637-639.

Daisley, H., Charles, W., Landeau, P., Jackman, L., Batson, M., and Gomez-Adams, K. (1991). Screening for HTLV-1 in healthy blood donors in Trinidad and Tobago, West Indies. Trop. Med. Parasitol. 42, 404-406.

Dalekos, G. N., Zervou, E., Karabini, F., Elisaf, M., Bourantas, K., and Siamopoulos, K. C. (1995). Prevalence of antibodies to human Tlymphotropic virus types I and II in volunteer blood donors and highrisk groups in northwestern Greece. Transfusion 35, 503-506.

Davidson, F., Lycett, C., Jarvis, L. M., Kerr, D., Lumley, S., Petrik, J., et al. (2006). Detection of HTLV-I and II in Scottish blood donor samples and archive donations. Vox Sang. 91, 231-236.

de Oliveira, M. S., Matutes, E., Famadas, L. C., Schulz, T. F., Calabro, M. L., Nucci, M., et al. (1990). Adult T-cell leukaemia/lymphoma in Brazil and its relation to HTLV-I. Lancet 336, 987-990.

de Rivera, I. L., Amador, L., Mourra, S., Li, Z., and Rasheed, S. (1995). Geographical clustering of human T-cell lymphotropic virus type 1 infection in Honduras. J. Clin. Microbiol. 33, 2999-3003.

de The, G., and Bomford, R. (1993). An HTLV-I vaccine: why, how, for whom? AIDS Res. Hum. Retroviruses 9, 381-386.

de The, G., and Gessain, A. (1986). Seroepidemiologic data on viral infections (HTLV-I and LAV/HTLVIII) in the Caribbean region and intertropical Africa. Ann. Pathol. 6, 261-264.

Dekaban, G. A., Oger, J. J., Foti, D., King, E. E., Waters, D. J., Picard, F. J., et al. (1994). HTLV-I infection associated with disease in aboriginal Indians from British Columbia: a serological and PCR analysis. Clin. Diagn. Virol. 2, 67-78.

Del Mistro, A., Chotard, J., Hall, A. J., Fortuin, M., Whittle, H., De Rossi A., et al. (1994). HTLV-I/II seroprevalence in the Gambia: a study of mother-child pairs. AIDS Res. Hum. Retroviruses 10, 617-620.

Delaporte, E., Buve, A., Nzila, N., Goeman, J., Dazza, M. C., Henzel, D., et al. (1995). HTLV-I infection among prostitutes and pregnant women in Kinshasa, Zaire: how important is high-risk sexual behavior? J. Acquir. Immune Defic. Syndr. Hum. Retrovirol. 8, 511-515.

Delaporte, E., Dupont, A., Peeters, M., Josse, R., Merlin, M., Schrijvers, D., et 
al. (1988). Epidemiology of HTLVI in Gabon (Western Equatorial Africa). Int. J. Cancer 42, 687-689.

Delaporte, E., Monplaisir, N., Louwagie, J., Peeters, M., Martin-Prevel, Y., Louis, J. P., et al. (1991). Prevalence of HTLV-I and HTLV-II infection in Gabon, Africa: comparison of the serological and PCR results. Int. J. Cancer 49, 373-376.

Delaporte, E., Peeters, M., Durand, J. P., Dupont, A., Schrijvers, D., Bedjabaga, L., et al. (1989a). Seroepidemiological survey of HTLV-I infection among randomized populations of western central African countries. J. Acquir. Immune Defic. Syndr. 2, 410-413.

Delaporte, E., Peeters, M., Simoni, M., and Piot, P. (1989b). HTLV-I infection in western equatorial Africa. Lancet 2, 1226.

Denic, S., Abramson, J., Anandakrishnan, R., Krishnamurthy, M., and Dosik, H. (1988). The first report of familial adult T-cell leukemia lymphoma in the United States. Am. J. Hematol. 27, 281-283.

Denic, S., Nolan, P., Doherty, J., Garson, J., Tuke, P., and Tedder, R. (1990). HTLV-I infection in Iraq. Lancet 336, 1135-1136.

Denis, F., Verdier, M., Chout, R., Ramiandrisoa, H., Sangare, A., Prince-David, M., et al. (1988). Prevalence of HTLV-1 virus in pregnant women in Black Africa, Martinique, and foreigners living in France. Bull. Acad. Natl. Med. 172, 717-722.

de-The, G., Gessain, A., Gazzolo, L., Robert-Guroff, M., Najberg, G., Calender, A., et al. (1985). Comparative seroepidemiology of HTLV-I and HTLV-III in the French West Indies and some African countries. Cancer Res. 45, 4633s-4636s.

Diop, S., Calattini, S., Abah-Dakou, J., Thiam, D., Diakhate, L., and Gessain, A. (2006). Seroprevalence and molecular epidemiology of human TCell leukemia virus type 1 (HTLV- 1 ) and HTLV-2 in blood donors from Dakar, Senegal. J. Clin. Microbiol.44, 1550-1554.

Dixon, P. S., Bodner, A. J., Okihiro, M., Milbourne, A., Diwan, A., and Nakamura, J. M. (1990). Human Tlymphotropic virus type I (HTLVI) and tropical spastic paraparesis or HTLV-I-associated myelopathy in Hawaii. West. J. Med. 152, 261-267.

Dosik, H., Denic, S., Patel, N., Krishnamurthy, M., Levine, P. H., and Clark, J. W. (1988). Adult T-cell leukemia/lymphoma in Brooklyn. JAMA 259, 2255-2257.
Dougan, S., Smith, A., Tosswill, J. C., Davison, K., Zuckerman, M., and Taylor, G. P. (2005). New diagnoses of HTLV infection in England and Wales: 2002-2004. Euro Surveill. 10, 232-235.

Dourado, I., Alcantara, L. C., Barreto, M. L., da Gloria Teixeira, M., and Galvao-Castro, B. (2003). HTLV-I in the general population of Salvador, Brazil: a city with African ethnic and sociodemographic characteristics. J. Acquir. Immune Defic. Syndr. 34, 527-531.

Dowe, G., King, S. D., Smikle, M. F., Wynter, H. H., Chout, R., and Klaskala, W. (1998). Prevalence of viral and bacterial sexually transmitted pathogens in Jamaican pregnant women. West Indian Med. J. 47, 23-25.

Dumas, M., Houinato, D., Verdier, M., Zohoun, T., Josse, R., Bonis, J., et al. (1991). Seroepidemiology of human T-cell lymphotropic virus type I/II in Benin (West Africa). AIDS Res. Hum. Retroviruses 7, 447-451.

Duval, A., Rivet, J., Moulonguet, I., Cassar, O., Agbalika, F., Wallach, D., et al. (2010). Atypical presentation of adult T-cell leukaemia/lymphoma due to HTLV-1: prurigo nodularis lasting twelve years followed by an acute micropapular eruption. Acta Derm. Venereol. 90, 287-290.

Eguchi, K., Fujii, H., Oshima, K., Otani, M., Matsuo, T., and Yamamoto, T. (2009). Human T-lymphotropic virus type 1 (HTLV-1) genetic typing in Kakeroma Island, an island at the crossroads of the ryukyuans and Wajin in Japan, providing further insights into the origin of the virus in Japan. J. Med. Virol. 81, 1450-1456.

Einsiedel, L., Fernandes, L., Spelman, T., Steinfort, D., and Gotuzzo, E. (2012). Bronchiectasis is associated with human T-lymphotropic virus 1 infection in an Indigenous Australian population. Clin. Infect. Dis. 54, 43-50.

Einsiedel, L., Verdonck, K., and Gotuzzo, E. (2010). "Human T-lymphotropic virus 1 : clinical aspects of a neglected infection among indigenous populations," in Emerging Infections, Vol. 9, eds M. W. Scheld, L. M. Grayson, and M. J. Hughes (Washington, DC: ASM Press), 109-127.

el-Farrash, M. A., Badr, M. F., Hawas, S. A., el-Nashar, N. M., Imai, J., Komoda, H., et al. (1988). Sporadic carriers of human T-lymphotropic virus type $I$ in northern Egypt. Microbiol. Immunol. 32, 981-984.

El-ghazzawi, E., Hunsmann, G., and Schneider, J. (1987). Low prevalence of antibodies to HIV-1 and HTLV-I in Alexandria, Egypt. AIDS Forsch. 2, 639.

El-Hazmi, M. M. (2004). Prevalence of HBV, HCV, HIV-1, 2 and HTLV-I/II infections among blood donors in a teaching hospital in the Central region of Saudi Arabia. Saudi Med. J. 25, 26-33.

Engelbrecht, S., Koulinska, I., Smith, T. L., Robson, B. A., Barreto, J., and van Rensburg, E. J. (1999). Subtyping of human $\mathrm{T}$ cell lymphotropic virus type I from tropical spastic paraparesis/HTLV-associated myelopathy patients in Mozambique. AIDS Res. Hum. Retroviruses $15,71-72$.

Estrada, R. A., Luis, S., Mustelier, R., Ruiz, W., Rodriguez, B., Miranda, A., et al. (1995). Absence of human retroviral antibodies in epidemic neuropathy in Cuba: report of the first two cases of HTLV-I-associated tropical spastic paraparesis observed in Cuba. J. Neurol. Sci. 128, 112-113.

Etenna, S. L., Caron, M., Besson, G., Makuwa, M., Gessain, A., Mahe, A., et al. (2008). New insights into prevalence, genetic diversity, and proviral load of human T-cell leukemia virus types 1 and 2 in pregnant women in Gabon in equatorial central Africa. J. Clin. Microbiol. 46 3607-3614.

Ferrante, P., Mancuso, R., Zuffolato, R., Puricelli, S., Mannella, E., Romano, L., et al. (1997). Molecular analysis of HTLV-I and HTLV-II isolates from Italian blood donors, intravenous drug users and prisoners. New Microbiol. 20, 93-104.

Figueiro-Filho, E. A., Senefonte, F. R., Lopes, A. H., de Morais, O. O., Souza Junior, V. G., Maia, T. L., et al. (2007). Frequency of HIV1, rubella, syphilis, toxoplasmosis, cytomegalovirus, simple herpes virus, hepatitis $\mathrm{B}$, hepatitis $\mathrm{C}$, Chagas disease and HTLV I/II infection in pregnant women of State of Mato Grosso do Sul. Rev. Soc. Bras. Med. Trop. 40, 181-187.

Filippone, C., Bassot, S., Betsem, E., Tortevoye, P., Guillotte, M., Mercereau-Puijalon, O., et al. (2012). A new and frequent human $\mathrm{T}$-cell leukemia virus indeterminate Western blot pattern: epidemiological determinants and PCR results in central African inhabitants. J. Clin. Microbiol. 50, 1663-1672.

Fleming, A. F., Maharajan, R., Abraham, M., Kulkarni, A. G., Bhusnurmath, S. R., Okpara, R. A., et al. (1986). Antibodies to HTLV-I in Nigerian blooddonors, their relatives and patients with leukaemias, lymphomas and other diseases. Int. J. Cancer 38, 809-813.

Fouchard, N., Mahe, A., Huerre, M., Fraitag, S., Valensi, F., Macintyre, E., et al. (1998). Cutaneous T cell lymphomas: mycosis fungoides, Sezary syndrome and HTLV-I-associated adult $\mathrm{T}$ cell leukemia (ATL) in Mali, West Africa: a clinical, pathological and immunovirological study of 14 cases and a review of the African ATL cases. Leukemia 12, 578-585.

Freeman, R. C., Rodriguez, G. M. and French, J. F. (1995). Seroprevalence and risk factors associated with HTLV-I/II infection in injection drug users in northern New Jersey. J. Addict. Dis. 14, 51-66.

Fujiyoshi, T., Li, H. C., Lou, H., Yashiki, S., Karino, S., Zaninovic, V., et al. (1999). Characteristic distribution of HTLV type I and HTLV type II carriers among native ethnic groups in South America. AIDS Res. Hum. Retroviruses 15, 1235-1239.

Furusyo, N., Hayashi, J., Kakuda, K., Sawayama, Y., Ariyama, I., Eddie, R., et al. (1999). Markedly high seroprevalence of hepatitis B virus infection in comparison to hepatitis $\mathrm{C}$ virus and human $\mathrm{T}$ lymphotropic virus type-1 infections in selected Solomon Islands populations. Am. J. Trop. Med. Hyg. 61, 85-91.

Gabarre, J., Gessain, A., Raphael, M., Merle-Beral, H., Dubourg, O., Fourcade, C., et al. (1993). Adult T-cell leukemia/lymphoma revealed by a surgically cured cardiac valve lymphomatous involvement in an Iranian woman: clinical, immunopathological and viromolecular studies. Leukemia 7, 1904-1909.

Galvao-Castro, B., Loures, L., Rodriques, L. G., Sereno, A., Ferreira Junior, O. C., Franco, L. G., et al. (1997). Distribution of human T-lymphotropic virus type I among blood donors: a nationwide Brazilian study. Transfusion 37, 242-243.

Gascoyne, R. D., Kim, S. M., Oger, J. J., Melosky, B. L., and Dekaban, G. A. (1996). HTLV-I associated adult $\mathrm{T}$ cell leukemia/lymphoma: report of two cases from an Amerindian population in coastal northwest British Columbia. Leukemia 10, 552-557.

Gasmi, M., Farouqi, B., d'Incan, M., and Desgranges, C. (1994). Long terminal repeat sequence analysis of HTLV type I molecular variants identified in four north African patients. AIDS Res. Hum. Retroviruses 10, 1313-1315. 
Gastaldello, R., Hall, W. W., and Gallego, S. (2004). Seroepidemiology of HTLV-I/II in Argentina: an overview. J. Acquir. Immune Defic. Syndr. 35, 301-308.

Gerard, Y., Lepere, J. F., Pradinaud, R., Joly, F., Lepelletier, L., Joubert, M., et al. (1995). Clustering and clinical diversity of adult Tcell leukemia/lymphoma associated with HTLV-I in a remote black population of French Guiana. Int. J. Cancer 60, 773-776.

Gessain, A. (2011). Human retrovirus HTLV-1: descriptive and molecular epidemiology, origin, evolution, diagnosis and associated diseases. Bull. Soc. Pathol. Exot. 104, 167-180.

Gessain, A., Caumes, E., Feyeux, C., d'Agay, M. F., Capesius, C., Gentilini, M., et al. (1992a). The cutaneous form of adult T-cell leukemia/lymphoma in a woman from the Ivory Coast. Clinical, immunovirologic studies and a review of the African adult T-cell leukemia/lymphoma cases. Cancer 69, 1362-1367.

Gessain, A., Gallo, R. C., and Franchini, G. (1992b). Low degree of human T-cell leukemia/lymphoma virus type I genetic drift in vivo as a means of monitoring viral transmission and movement of ancient human populations. J. Virol. 66, 2288-2295.

Gessain, A., and de The, G. (1996). What is the situation of human T cell lymphotropic virus type II (HTLVII) in Africa? Origin and dissemination of genomic subtypes. J. Acquir. Immune Defic. Syndr. Hum. Retrovirol. 13(Suppl. 1), S228-S235.

Gessain, A., Fretz, C., Koulibaly, M., Boudret, M. L., Bah, A., Raphael, M., et al. (1993a). Evidence of HTLVII infection in Guinea, West Africa. J. Acquir. Immune Defic. Syndr. 6, 324-325.

Gessain, A., Herve, V., Jeannel, D., Garin, B., Mathiot, C., and de-The, G. (1993b). HTLV-1 but not HTLV2 found in pygmies from Central African Republic. J. Acquir. Immune Defic. Syndr. 6, 1373-1374.

Gessain, A., Gout, O., Saal, F., Daniel, M. T., Rio, B., Flandrin, G., et al. (1990a). Epidemiology and immunovirology of human T-cell leukemia/lymphoma virus type Iassociated adult T-cell leukemia and chronic myelopathies as seen in France. Cancer Res. 50, 5692S5696S.

Gessain, A., Moulonguet, I., Flageul, B., Perrin, P., Capesius, C., D’Agay, M. F., et al. (1990b). Cutaneous type of adult $\mathrm{T}$ cell leukemia/lymphoma in a French West Indian woman. Clonal rearrangement of $\mathrm{T}$-cell receptor beta and gamma genes and monoclonal integration of HTLVI proviral DNA in the skin infiltrate. J. Am. Acad. Dermatol. 23, 994-1000.

Gessain, A., Saal, F., Gout, O., Daniel, M. T., Flandrin, G., de The, G., et al. (1990c). High human T-cell lymphotropic virus type I proviral DNA load with polyclonal integration in peripheral blood mononuclear cells of French West Indian, Guianese, and African patients with tropical spastic paraparesis. Blood $75,428-433$

Gessain, A., Yanagihara, R., Franchini, G., Garruto, R. M., Jenkins, C. L., Ajdukiewicz, A. B., et al. (1991). Highly divergent molecular variants of human T-lymphotropic virus type I from isolated populations in Papua New Guinea and the Solomon Islands. Proc. Natl. Acad. Sci. U.S.A. 88, 7694-7698.

Gharibi, L., Marouan, S., Zouhair, K., Benchekroun, M., and Benchikhi, H. (2011). Fatal erythroderma in a young Moroccan. Med. Trop. (Mars) 71, 189-191.

Gibbs, W. N., Lofters, W. S., Campbell, M., Hanchard, B., LaGrenade, L., Clark, J., et al. (1984). Adult Tcell leukemia/lymphoma in Jamaica and its relationship to human T-cell leukemia/lymphoma virus type I-associated lymphoproliferative disease. Int. Symp. Princess Takamatsu Cancer Res. Fund 15, 77-90.

Gioseffi, O. N., Nucifora, E., Fantl, D., Dufour, C., Milone, J., and Di Paolo, H. (1995). Adult HTLVI positive leukemia-lymphoma in Argentina. Sangre (Barc) 40, 421-424.

Gongora-Biachi, R. A., GonzalezMartinez, P., Castro-Sansores, C., and Bastarrachea-Ortiz, J. (1997). Infection with HTLV virus type I-II in patients with cervico-uterine cancer in the Yucatan peninsula, Mexico. Ginecol. Obstet. Mex. 65, 141-144.

Gongora-Biachi, R. A., GonzalezMartinez, P., Castro-Sansores, C., Vivas-Rosel, M. L., GasqueLopez, F., and Garrido-Hadad, E. (1996). Lymphotropic viruses type I and II in pregnant women in Yucatan. Rev. Invest. Clin. 48, 383-384.

Goto, K., Sato, K., Kurita, M., Masuhara, N., Iijima, Y., Saeki, K., et al. (1997). Serologic survey for HTLV-I in Kanagawa Prefecture. Tokai J. Exp. Clin. Med. 22, 7-8.
Gotuzzo, E., Cabrera, J., Deza, L. Verdonck, K., Vandamme, A. M., Cairampoma, R., et al. (2004). Clinical characteristics of patients in Peru with human $\mathrm{T}$ cell lymphotropic virus type 1-associated tropical spastic paraparesis. Clin. Infect. Dis. 39, 939-944.

Goubau, P., Carton, H., Kazadi, K., Muya, K. W., and Desmyter, J. (1990). HTLV seroepidemiology in a central African population with high incidence of tropical spastic paraparesis. Trans. R. Soc. Trop. Med. Hyg. 84, 577-579.

Goubau, P., Desmyter, J., Swanson, P., Reynders, M., Shih, J., Surmont, I., et al. (1993). Detection of HTLV-I and HTLV-II infection in Africans using type-specific envelope peptides. J. Med. Virol. 39, 28-32.

Gout, O., Gessain, A., Bolgert, F., Saal, F., Tournier-Lasserve, E. Lasneret, J., et al. (1989). Chronic myelopathies associated with human T-lymphotropic virus type I. A clinical, serologic, and immunovirologic study of ten patients in France. Arch. Neurol. 46, 255-260.

Gracia, F., Reeves, W. C., Levine, P. H., Cuevas, M., Castillo, L., Chavarria, R., et al. (1990). Human T-cell lymphotropic virus type I and neurologic disease in Panama, 1985 and 1986. Arch. Neurol. 47, 634-639.

Gradilone, A., Zani, M., Barillari, G., Modesti, M., Agliano, A. M., Maiorano, G., et al. (1986). HTLV-I and $\mathrm{HIV}$ infection in drug addicts in Italy. Lancet 2, 753-754

Grant, W., Bia, F. J., Chacko, T. M., Jean-Baptiste, M., and Griffith, B. P. (1992). Comparison of enzymelinked immunosorbent and indirect immunofluorescence assays for the detection of human T-cell lymphotropic virus type-I antibodies in sera from rural Haiti. Diagn. Microbiol. Infect. Dis. 15, 121-124.

Group, R. S. (1989). Nationwide community-based serological survey of HIV-1 and other human retrovirus infections in a central African country. Rwandan HIV Seroprevalence Study Group. Lancet 1, 941-943.

Gudo, E. S., Abreu, C. M., Mussa T., Augusto Ado, R., Otsuki, K., Chambo, E., et al. (2009). Serologic and molecular typing of human Tlymphotropic virus among blood donors in Maputo City, Mozambique. Transfusion 49, 1146-1150.

Guimaraes de Souza, V., Lobato Martins, M., de Freitas Carneiro-Proietti, A. B., Januario, J. N., Ladeira, R. V., Silva, C. M., et al. (2012). High prevalence of HTLV-1 and 2 viruses in pregnant women in Sao Luis, state of Maranhao, Brazil. Rev. Soc. Bras. Med. Trop. 45, 159-162.

Guo, H. G., Wong-Stall, F., and Gallo, R. C. (1984). Novel viral sequences related to human $\mathrm{T}$-cell leukemia virus in $\mathrm{T}$ cells of a seropositive baboon. Science 223, 1195-1197.

Hale, A., Leung, T., Sivasubramaniam, S., Kenny, J., and Sutherland, S. (1997). Prevalence of antibodies to HTLV in antenatal clinic attenders in south east London. J. Med. Virol. 52, 326-329.

Haque, A., Hossain, M., Khan, J. K., Kuo, Y. H., Lambein, F., and De Reuck, J. (1994). New findings and symptomatic treatment for neurolathyrism, a motor neuron disease occurring in north west Bangladesh. Paraplegia 32, 193-195.

Harrington, W. J. Jr., Ucar, A., Gill, P., Snodgrass, S., Sheremata, W., Cabral, L., et al. (1995). Clinical spectrum of HTLV-I in south Florida. J. Acquir. Immune Defic. Syndr. Hum. Retrovirol. 8, 466-473.

Hayami, M., Komuro, A., Nozawa, K., Shotake, T., Ishikawa, K., Yamamoto, K., et al. (1984). Prevalence of antibody to adult T-cell leukemia virus-associated antigens (ATLA) in Japanese monkeys and other nonhuman primates. Int. J. Cancer 33, 179-183.

Hernandez Ramirez, P., Rivero Jimenez, R., Ballester Santovenia, M., Navea Leyva, L., Matutes, E., Catovsky, D., et al. (1991). Very low seroprevalence of HTLV-I/II in Cuba: antibodies in blood donors and in hematological and nonhematological patients. Vox Sang. 61, 277-278.

Hino, S. (2011). Establishment of the milk-borne transmission as a key factor for the peculiar endemicity of human T-lymphotropic virus type 1 (HTLV-1): the ATL prevention program Nagasaki. Proc. Jpn. Acad. Ser. B Phys. Biol. Sci. 87, 152-166.

Hino, S., Katamine, S., Kawase, K. Miyamoto, T., Doi, H., Tsuji, Y., et al. (1994). Intervention of maternal transmission of HTLV-1 in Nagasaki, Japan. Leukemia 8 (Suppl. 1), S68-S70.

Hino, S., Sugiyama, H., Doi, H., Ishimaru, T., Yamabe, T., Tsuji, Y., et al. (1987). Breaking the cycle of HTLVI transmission via carrier mothers' milk. Lancet 2, 158-159.

Hino, S., Yamaguchi, K., Katamine, S., Sugiyama, H., Amagasaki, T., Kinoshita, K., et al. (1985). Mother-to-child transmission of human T-cell leukemia virus type-I. Jpn. J. Cancer Res. 76, 474-480. 
Hinuma, Y., Komoda, H., Chosa, T., Kondo, T., Kohakura, M., Takenaka, T., et al. (1982). Antibodies to adult T-cell leukemia-virusassociated antigen (ATLA) in sera from patients with ATL and controls in Japan: a nation-wide seroepidemiologic study. Int. J. Cancer 29, 631-635.

Hlela, C., Shepperd, S., Khumalo, N. P., and Taylor, G. P. (2009). The prevalence of human T-cell lymphotropic virus type 1 in the general population is unknown. AIDS Rev. 11, 205-214.

Homma, T., Kanki, P. J., King, N. W. Jr., Hunt, R. D., O'Connell, M. J., Letvin, N. L., et al. (1984). Lymphoma in macaques: association with virus of human T lymphotrophic family. Science $225,716-718$.

Houinato, D., Verdier, M., Josse, R., Zohoun, T., Letenneur, L., Salamon, R., et al. (1996). Seroepidemiological study of retroviruses (HTLV-I/II, HIV-1, HIV-2) in the Department of Atacora, northern Benin. Trop. Med. Int. Health 1, 205-209.

Houston, S., Thornton, C., Emmanuel, J., and Latif, A. (1994). Human T cell lymphotropic virus type 1 in Zimbabwe. Trans. R. Soc. Trop. Med. Hyg. 88, 170-172.

Hunsmann, G., Bayer, H., Schneider, J., Schmitz, H., Kern, P., Dietrich, M., et al. (1984). Antibodies to ATLV/HTLV-1 in Africa. Med. Microbiol. Immunol. 173, 167-170.

Hunsmann, G., Schneider, J., Schmitt, J., and Yamamoto, N. (1983). Detection of serum antibodies to adult T-cell leukemia virus in non-human primates and in people from Africa. Int. J. Cancer 32, 329-332.

Inaba, S., Sato, H., Okochi, K., Fukada, K., Takakura, F., Tokunaga, K., et al. (1989). Prevention of transmission of human T-lymphotropic virus type 1 (HTLV-1) through transfusion, by donor screening with antibody to the virus. One-year experience. Transfusion 29, 7-11.

Ishida, T., and Hinuma, Y. (1986). The origin of Japanese HTLV-I. Nature 322, 504.

Ishida, T., Yamamoto, K., and Omoto, K. (1988). A seroepidemiological survey of HTLV-1 in the Philippines. Int. J. Epidemiol. 17, 625-628.

Jain, P., Gupta, S., Prabhash, K., Patkar, N., and Parikh, P. M. (2008). Adult $\mathrm{T}$ cell leukemia: a typical case from India. Indian J. Cancer 45, $72-73$.

Janssen, R. S., Kaplan, J. E., Khabbaz, R. F., Hammond, R., Lechtenberg, R., Lairmore, M., et al. (1991). HTLVI-associated myelopathy/tropical spastic paraparesis in the United States. Neurology 41, 1355-1357.

Jeannel, D., Garin, B., Kazadi, K., Singa, L., and de The, G. (1993). The risk of tropical spastic paraparesis differs according to ethnic group among HTLV-I carriers in Inongo, Zaire. J. Acquir. Immune Defic. Syndr. 6, 840-844.

Jeannel, D., Kourouma, K., Fretz, C., Zheng, Y. M., Ureta, V. A., Drame, L., et al. (1995). Regional differences in human retroviral infections HIV-1, HIV-2, and HTLV-I/II in rural Guinea (west Africa). J. Acquir. Immune Defic. Syndr. Hum. Retrovirol. 8, 315-318.

Jeon, H. J., Lee, M. J., Jeong, Y. K., Lee, D. M., Oh, Y. K., and Kim, C. W. (2000). Adult $\mathrm{T}$ cell leukemia/lymphoma with lymphopenia in a Korean. J. Korean Med. Sci. 15, 233-239.

Jogessar, V. B., de Bruyn, C. C., Bhigjee, A. I., Naicker, V. L., Bill, P. L., and Tait, D. (1992). Adult Tcell leukaemia/lymphoma associated with HTLV-I in Natal. S. Afr. Med. J. 81, 528-529.

Joubert, J., van As, A. D., Lecatsas, G., and Bos, P. (1991). Human T-lymphotropic virus type Iassociated myelopathy. A case report. S. Afr. Med. J. 80, 592-593.

Kajiyama, W., Kashiwagi, S., Ikematsu, H., Hayashi, J., Nomura, H., and Okochi, K. (1986). Intrafamilial transmission of adult $\mathrm{T}$ cell leukemia virus. J. Infect. Dis. 154, 851-857.

Kaplan, J. E., Khabbaz, R. F., Murphy, E. L., Hermansen, S., Roberts, C., Lal, R., et al. (1996). Male-tofemale transmission of human Tcell lymphotropic virus types I and II: association with viral load. The Retrovirus Epidemiology Donor Study Group. J. Acquir. Immune Defic. Syndr. Hum. Retrovirol. 12, 193-201.

Kawashti, M. I., Hindawi, S. I., Damanhouri, G. A., Rowehy, N. G., Bawazeer, M. M., and Alshawa, M. (2005). Serologial screening of human $\mathrm{T}$ cell lymphotropic virus I and II (HTLV I/II) in blood banks by immunoblotting and enzymeimmuno assays: to demand or to defeat? Egypt J. Immunol. 12, 137-142.

Kayembe, K., Goubau, P., Desmyter, J., Vlietinck, R., and Carton, H. (1990). A cluster of HTLV-1 associated tropical spastic paraparesis in Equateur (Zaire): ethnic and familial distribution. J. Neurol. Neurosurg. Psychiatr. 53, 4-10.

Kazanji, M., and Gessain, A. (2003). Human T-cell Lymphotropic Virus types I and II (HTLV-I/II) in French
Guiana: clinical and molecular epidemiology. Cad. Saude Publica 19, 1227-1240.

Kchour, G., Tarhini, M., Kooshyar, M. M., El Hajj, H., Wattel, E., Mahmoudi, M., et al. (2009). Phase 2 study of the efficacy and safety of the combination of arsenic trioxide, interferon alpha, and zidovudine in newly diagnosed chronic adult $\mathrm{T}$-cell leukemia/lymphoma (ATL). Blood 113, 6528-6532.

Khabbaz, R. F., Hartley, T. M. Oberle, M. W., and Rosero-Bixby, L. (1990). Seroprevalence of human T-lymphotropic virus type I (HTLVI) in Costa Rica. AIDS Res. Hum. Retroviruses 6, 959-960.

Kim, J. M., Song, Y. G., Oho, Y. C., Park, H. C., Kwon, K. H., Kim, E., et al. (1999). Antibodies to human T-cell lymphotropic virus type I (HTLV-I) by particle agglutination (PA) test in Korean blood donors. Yonsei Med. J. 40, 173-177.

Kimata, J. T., Kaneshiro, S. A., Kwock, D. W., Nakamura, S., Kaneshiro, M. M., and Nakamura, J. M. (1989). A seroepidemiologic survey of human T-cell lymphotropic virus type I in two Hawaiian hematologiconcologic practices. West. J. Med. 150, 300-302.

Kinoshita, K., Hino, S., Amagaski, T., Ikeda, S., Yamada, Y., Suzuyama, J., et al. (1984). Demonstration of adult $\mathrm{T}$-cell leukemia virus antigen in milk from three sero-positive mothers. Gann 75, 103-105.

Kirkland, M. A., Frasca, J., and Bastian, I. (1991). Adult T-cell leukaemia lymphoma in an aborigine. Aust. N. Z. J. Med. 21, 739-741.

Kohakura, M., Nakada, K., Yonahara, M., Komoda, H., Imai, J., and Hinuma, Y. (1986). Seroepidemiology of the human retrovirus (HTLV/ATLV) in Okinawa where adult T-cell leukemia is highly endemic. Jpn. J. Cancer Res. 77, 21-23.

Koralnik, I. J., Boeri, E., Saxinger, W. C., Monico, A. L., Fullen, J., Gessain, A., et al. (1994). Phylogenetic associations of human and simian T-cell leukemia/lymphotropic virus type I strains: evidence for interspecies transmission. J. Virol. 68, 2693-2707.

Kumar, H., and Gupta, P. K. (2006). Is seroprevalence of HTLV-I/II among blood donors in India relevant? Indian J. Pathol. Microbiol. 49, 532-534.

Kwon, S. Y., Lim, A. H., Park, J. Y., Han, S. H., and Cho, N.S. (2008). Seroprevalence of human T-lymphotropic virus type 1 and 2 in Korean blood donors. J. Med. Virol. 80, 1864-1867.

La Grenade, L., Hanchard, B., Fletcher, V., Cranston, B., and Blattner, W. (1990). Infective dermatitis of Jamaican children: a marker for HTLV-I infection. Lancet 336, 1345-1347.

Laperche, S., Worms, B., and Pillonel, J. (2009). Blood safety strategies for human T-cell lymphotropic virus in Europe. Vox Sang. 96, 104-110.

Larsen, O., Andersson, S., da Silva, Z. Hedegaard, K., Sandstrom, A., Naucler, A., et al. (2000). Prevalences of HTLV-1 infection and associated risk determinants in an urban population in Guinea-Bissau, West Africa. J. Acquir. Immune Defic. Syndr. 25, 157-163.

Lavanchy, D., Bovet, P., Hollanda, J., Shamlaye, C. F., Burczak, J. D., and Lee, H. (1991). High seroprevalence of HTLV-I in the Seychelles. Lancet 337, 248-249.

Le Hesran, J. Y., Delaporte, E., Gaudebout, C., Trebuck, A., Schrijvers, D. Josse, R., et al. (1994). Demographic factors associated with HTLV-1 infection in a Gabonese community. Int. J. Epidemiol. 23, 812-817.

Lechat, M. F., Shrager, D. I., Declercq, E., Bertrand, F., Blattner, W. A., and Blumberg, B. S. (1997). Decreased survival of HTLV-I carriers in leprosy patients from the Democratic Republic of the Congo: a historical prospective study. J. Acquir. Immune Defic. Syndr. Hum. Retrovirol. 15, 387-390.

Lee, C. W., Chang, M. C., Chang, Y. F., Hsieh, R. K., Lin, J., and Chen, K. S. (2010). Adult T-cell leukemia/lymphoma in Taiwan: an analysis of 17 patients and review of the literature. Asia Pac. J. Clin. Oncol. 6, 161-164.

Lee, H. H., Weiss, S. H., Brown, L. S., Mildvan, D., Shorty, V., Saravolatz, L., et al. (1990). Patterns of HIV-1 and HTLV-I/II in intravenous drug abusers from the middle atlantic and central regions of the USA. J. Infect. Dis. 162, 347-352.

Lee, S. Y., Yamaguchi, K., Takatsuki, K., Kim, B. K., Park, S., and Lee, M. (1986). Seroepidemiology of human T-cell leukemia virus type-I in the Republic of Korea. Jpn. J. Cancer Res. 77, 250-254.

Leon, G., Quiros, A. M., Lopez, J. L., Hung, M., Diaz, A. M., Goncalves, J., et al. (2003). Seropositivity for human T-lymphotropic virus types I and II among donors at the Municipal Blood Bank of Caracas and associated risk factors. Rev. Panam. Salud Publica 13, 117-123. 
Levine, P. H., Reeves, W. C., Cuevas, M., Arosemena, J. R., Jaffe, E. S., Saxinger, W. C., et al. (1989). Human T-cell leukemia virus-I and hematologic malignancies in Panama. Cancer 63, 2186-2191.

Li, H. C., Biggar, R. J., Miley, W. J., Maloney, E. M., Cranston, B., Hanchard, B., et al. (2004). Provirus load in breast milk and risk of motherto-child transmission of human $\mathrm{T}$ lymphotropic virus type I. J. Infect. Dis. 190, 1275-1278.

Louis, F. J., Sapin, C., Huerre, M., Desforges, S., Labrouasse, R., Friquet, I., et al. (1990). Prévalence à Wallis des trépanomatoses et des infections à virus HTLV-1 et $\mathrm{HB}$. Médecine d'Océanie 2, 28-32.

Louisiriotchanakul, S., Thongput, A., Khamboonruang, C., Taylor, G. P., Kunstadter, P., and Wasi, C. (2000). No evidence of HTLV-I or HTLVII infection among the Hmong people of northern Thailand or injecting drug users in Bangkok. J. Acquir. Immune Defic. Syndr. 23, 441-442.

Lu, S. C., Kao, C. L., Chin, L. T., Chen, J. W., Yang, C. M., Chang, J. H., et al. (2001). Seroprevalence and demographic characteristics of HTLV-I among blood donors in Taiwan: 1996-1999. Int. J. Hematol. 74, 333-337.

Machuca, A., Tuset, C., Soriano, V., Caballero, E., Aguilera, A., and Ortiz de Lejarazu, R. (2000). Prevalence of HTLV infection in pregnant women in Spain. Sex. Transm. Infect. 76, 366-370.

Maeda, Y., Furukawa, M., Takehara, Y., Yoshimura, K., Miyamoto, K., Matsuura, T., et al. (1984). Prevalence of possible adult T-cell leukemia viruscarriers among volunteer blood donors in Japan: a nation-wide study. Int. J. Cancer 33, 717-720.

Maehama, T. (2004). Human T cell leukemia virus-1 in pregnancy. Int. J. Gynaecol. Obstet. 87, 247-248.

Mahe, A., Gessain, A., Huerre, M., Valensi, F., Keita, S., and Bobin, P. (1994). Adult T-cell leukemia associated with HTLV-1 in a HIV-2 seropositive African. Ann. Dermatol. Venereol. 121, 704-709.

Mahieux, R., Chappey, C., GeorgesCourbot, M. C., Dubreuil, G., Mauclere, P., Georges, A., et al. (1998). Simian T-cell lymphotropic virus type 1 from Mandrillus sphinx as a simian counterpart of human T-cell lymphotropic virus type 1 subtype D. J. Virol. 72, 10316-10322.

Mahieux, R., and Gessain, A. (2009). The human HTLV-3 and HTLV4 retroviruses: new members of the HTLV family. Pathol. Biol. 57, 161-166.

Mahieux, R., Gessain, A., Truffert, A., Vitrac, D., Hubert, A., Dandelot, J., et al. (1994). Seroepidemiology, viral isolation, and molecular characterization of human $\mathrm{T}$ cell leukemia/lymphoma virus type I from La Reunion Island, Indian Ocean. AIDS Res. Hum. Retroviruses 10, 745-752.

Mahieux, R., Horal, P., Mauclere, P., Mercereau-Puijalon, O., Guillotte, M., Meertens, L., et al. (2000). Human T-cell lymphotropic virus type 1 gag indeterminate western blot patterns in Central Africa: relationship to Plasmodium falciparum infection. J. Clin. Microbiol. 38, 4049-4057.

Mahieux, R., Ibrahim, F., Mauclere, P., Herve, V., Michel, P., Tekaia, F., et al. (1997). Molecular epidemiology of 58 new African human T-cell leukemia virus type 1 (HTLV-1) strains: identification of a new and distinct HTLV-1 molecular subtype in Central Africa and in Pygmies. J. Virol. 71, 1317-1333.

Maloney, E. M., Yamano, Y., Vanveldhuisen, P. C., Sawada, T., Kim, N., Cranston, B., et al. (2006). Natural history of viral markers in children infected with human $\mathrm{T}$ lymphotropic virus type I in Jamaica. J. Infect. Dis. 194, 552-560.

Manca, N., Ferremi, P., De Simone, N., Pirali, F., and Turano, A. (1997). Isolation of HTLV-1 from an aggressive form of ATL in a Romanian patient not at risk of infection and with seronegative family members. New Microbiol. 20, 177-185.

Mansuy, J. M., Schlegel, L., Villeneuve, L., Mengelle, C., and Magnaval, J. F. (1999). Seroprevalence of retroviral infections among pregnant women in Martinique (French West Indies). Am. J. Trop. Med. Hyg. 61, 598-599.

Marin, O., Hasui, K., Remondegui, C., Sato, E., Aye, M. M., Takenouchi, N., et al. (2002). Adult Tcell leukemia/lymphoma in Jujuy, north-west Argentina. Pathol. Int. 52, 348-357.

Martin, F., Fedina, A., Youshya, S., and Taylor, G. P. (2010). A 15year prospective longitudinal study of disease progression in patients with HTLV-1 associated myelopathy in the UK. J. Neurol. Neurosurg. Psychiatr. 81, 1336-1340.

Mauclère, P., Afonso, P., Meertens, L., Plancoulaine, S., Calattini, S., Froment, A., et al. (2011). HTLV-2B strains, similar to those found in several Amerindians tribes, are endemic in Centra African Bakola Pygmies. J. Infect. Dis. 203, 1316-1323.

Mauclere, P., Le Hesran, J. Y., Mahieux, R., Salla, R., Mfoupouendoun, J., Abada, E. T., et al. (1997). Demographic, ethnic, and geographic differences between human $\mathrm{T}$ cell lymphotropic virus (HTLV) type I-seropositive carriers and persons with HTLV-I gag-indeterminate Western blots in Central Africa. J. Infect. Dis. 176, 505-509.

May, J. T., Stent, G., and Schnagl, R. D. (1988). Antibody to human T-cell lymphotropic virus type I in Australian aborigines. Med. J. Aust. 149, 104.

Meertens, L., Rigoulet, J., Mauclere, P., Van Beveren, M., Chen, G. M., Diop, O., et al. (2001). Molecular and phylogenetic analyses of 16 novel simian $\mathrm{T}$ cell leukemia virus type 1 from Africa: close relationship of STLV-1 from Allenopithecus nigroviridis to HTLV-1 subtype B strains. Virology 287, 275-285.

Michel, P., Develoux, M., Talarmin, F., Ndiaye, P., Ndiaye, M., Raphenon, G., et al. (1996). Pathologies associated with HTLV-1 virus in Dakar (1992-1995). Med. Trop. (Mars) 56, 249-254.

Miller, M., Achiron, A., Shaklai, M. Stark, P., Maayan, S., Hannig, H., et al. (1998). Ethnic cluster of HTLVI infection in Israel among the Mashhadi Jewish population. J. Med. Virol. 56, 269-274.

Miura, T., Fukunaga, T., Igarashi, T. Yamashita, M., Ido, E., Funahashi, S., et al. (1994). Phylogenetic subtypes of human T-lymphotropic virus type $I$ and their relations to the anthropological background. Proc. Natl. Acad. Sci. U.S.A. 91, 1124-1127.

Mochizuki, M., Watanabe, T., Yamaguchi, K., Tajima, K., Yoshimura, K., Nakashima, S., et al. (1992). Uveitis associated with human $\mathrm{T}$ lymphotropic virus type I: seroepidemiologic, clinical, and virologic studies. J. Infect. Dis. 166, 943-944.

Mojaat, N., Kaabi, H., Hmida, S., Maamar, M., Slama, S., and Boukef, K. (1999). Seroprevalence of HTLV-I/II antibodies in blood donors and different groups at risk in Tunisia. $J$. Acquir. Immune Defic. Syndr. 22, 314-315.

Mowbray, J., Mawson, S., Chawira, A., Skidmore, S., Boxall, E., Desselberger, U., et al. (1989). Epidemiology of human T-cell leukaemia/lymphoma virus type 1 (HTLV-1) infections in a subpopulation of Afro-Caribbean origin in England. J. Med. Virol. 29, 289-295.
Muchinik, G., Bouzas, M. B., Zapiola, I., Decaro, J., Garcia, L., Gallo, D., et al. (1992). HTLV-I and HTLV-II infection in Uruguay. J. Acquir. Immune Defic. Syndr. 5, 743-744.

Mueller, N. (1991). The epidemiology of HTLV-I infection. Cancer Causes Control 2, 37-52.

Murphy, E. L., Figueroa, J. P., Gibbs, W. N., Brathwaite, A., HoldingCobham, M., Waters, D., et al. (1989). Sexual transmission of human T-lymphotropic virus type I (HTLV-I). Ann. Intern. Med. 111, 555-560.

Murphy, E. L., Figueroa, J. P., Gibbs, W. N., Holding-Cobham, M., Cranston, B., Malley, K., et al. (1991). Human T-lymphotropic virus type I (HTLVI) seroprevalence in Jamaica. I. Demographic determinants. Am. J. Epidemiol. 133, 1114-1124.

Murphy, E. L., Watanabe, K., Nass, C. C., Ownby, H., Williams, A., and Nemo, G. (1999). Evidence among blood donors for a 30-year-old epidemic of human $\mathrm{T}$ lymphotropic virus type II infection in the United States. J. Infect. Dis. 180, 1777-1783.

Naman, R., Klayme, S., Naboulsi, M., Mokhbat, J., Jradi, O., and Ramia, S. (2002). HTLV-I and HTLV-II infections in volunteer blood donors and high-risk groups in Lebanon. $J$. Infect. 45, 29-31.

Nerrienet, E., Meertens, L., Kfutwah, A., Foupouapouognigni, Y., and Gessain, A. (2001). Molecular epidemiology of simian T-lymphotropic virus (STLV) in wild-caught monkeys and apes from Cameroon: a new STLV-1, related to human Tlymphotropic virus subtype $\mathrm{F}$, in a Cercocebus agilis. J. Gen. Virol. 82, 2973-2977.

Nicholson, S. R., Efandis, T., Dimitrakakis, M., Karopoulos, A., Lee, H., and Gust, I. D. (1992). HTLV-I infection in selected populations in Australia and the western Pacific region. Med. J. Aust. 156, 878-880.

Nightingale, S., Orton, D., Ratcliffe, D., Skidmore, S., Tosswill, J., and Desselberger, U. (1993). Antenatal survey for the seroprevalence of HTLV-1 infections in the West Midlands, England. Epidemiol. Infect. 110, 379-387.

Oger, J. J., Werker, D. H., Foti, D. J., and Dekaban, G. A. (1993). HTLV-I associated myelopathy: an endemic disease of Canadian aboriginals of the Northwest Pacific coast? Can. J. Neurol. Sci. 20, 302-306.

Ohkura, S., Yamashita, M., Cartier, L., Tanabe, D. G., Hayami, M., Sonoda, S., et al. (1999). Identification and phylogenetic characterization of a 
human T-cell leukaemia virus type I isolate from a native inhabitant (Rapa Nui) of Easter Island. J. Gen. Virol. 80(Pt 8), 1995-2001.

Oki, T., Yoshinaga, M., Otsuka, H., Miyata, K., Sonoda, S., and Nagata, Y. (1992). A sero-epidemiological study on mother-to-child transmission of HTLV-I in southern Kyushu, Japan. Asia Oceania J. Obstet. Gynaecol. 18, 371-377.

Okochi, K., Sato, H., and Hinuma, Y. (1984). A retrospective study on transmission of adult $\mathrm{T}$ cell leukemia virus by blood transfusion: seroconversion in recipients. Vox Sang. 46, 245-253.

Olaleye, D. O., Bernstein, L., Sheng, Z., Ekweozor, C. C., Li, X. Y., SullivanHalley, J., et al. (1994). Type-specific immune response to human $\mathrm{T}$ cell lymphotropic virus (HTLV) type I and type II infections in Nigeria. Am. J. Trop. Med. Hyg. 50, 479-486.

Olaleye, D. O., Ekweozor, C. C., Sheng, Z., and Rasheed, S. (1995). Evidence of serological cross-reactivities with human immunodeficiency virus types 1 and 2 and human Tlymphotropic virus types I and II in sera of pregnant women in Ibadan, Nigeria. Int. J. Epidemiol. 24, 198-203.

Olbrich Neto, J., and Meira, D. A. (2004). Soroprevalence of HTLVI/II, HIV, siphylis and toxoplasmosis among pregnant women seen at Botucatu - Sao Paulo - Brazil: risk factors for HTLV-I/II infection. Rev. Soc. Bras. Med. Trop. 37, 28-32.

Orland, J. R., Engstrom, J., Fridey, J., Sacher, R. A., Smith, J. W., Nass, C., et al. (2003). Prevalence and clinical features of HTLV neurologic disease in the HTLV outcomes study. Neurology 61, 1588-1594.

Osame, M., Janssen, R., Kubota, H., Nishitani, H., Igata, A., Nagataki, S., et al. (1990). Nationwide survey of HTLV-I-associated myelopathy in Japan: association with blood transfusion. Ann. Neurol. 28, 50-56.

Ouattara, S. A., Gody, M., and de-The, G. (1989). Prevalence of HTLV-I compared to HIV-1 and HIV-2 antibodies in different groups in the Ivory Coast (West Africa). J. Acquir. Immune Defic. Syndr. 2, 481-485.

Padua, E., Rodes, B., Perez-Pinar, T., Silva, A. F., Jimenez, V., Ferreira, F., et al. (2011). Molecular characterization of human $\mathrm{T}$ cell leukemia virus type 1 subtypes in a group of infected individuals diagnosed in Portugal and Spain. AIDS Res. Hum. Retroviruses 27, 317-322.

Park, J. H., Lee, B. I., Chun, S. I., and Osame, M. (1991). A case of HTLV-I associated myelopathy(HAM) in Korea. Yonsei Med. J. 32, 190-194.

Paun, L., Ispas, O., Del Mistro, A., and Chieco-Bianchi, L. (1994). HTLV-I in Romania. Eur. J. Haematol. 52, 117-118.

Payne, L. J., Tosswill, J. H., Taylor, G. P., Zuckerman, M., and Simms, I. (2004). In the shadow of HIV-HTLV infection in England and Wales, 1987-2001. Commun. Dis. Public Health 7, 200-206.

Pepin, J., Labbe, A. C., MamadouYaya, F., Mbelesso, P., Mbadingai, S., Deslandes, S., et al. (2010). Iatrogenic transmission of human $\mathrm{T}$ cell lymphotropic virus type 1 and hepatitis $\mathrm{C}$ virus through parenteral treatment and chemoprophylaxis of sleeping sickness in colonial Equatorial Africa. Clin. Infect. Dis. 51, 777-784.

Peters, A. A., Coulthart, M. B., Oger, J. J., Waters, D. J., Crandall, K. A., Baumgartner, A. A., et al. (2000). HTLV type I/II in British Columbia Amerindians: a seroprevalence study and sequence characterization of an HTLV type IIa isolate. AIDS Res. Hum. Retroviruses 16, 883-892.

Picard, F. J., Coulthart, M. B., Oger, J., King, E. E., Kim, S., Arp, J., et al. (1995). Human T-lymphotropic virus type 1 in coastal natives of British Columbia: phylogenetic affinities and possible origins. J. Virol. 69, 7248-7256.

Plancoulaine, S., Buigues, R. P., Murphy, E. L., van Beveren, M., Pouliquen, J. F., Joubert, M., et al. (1998). Demographic and familial characteristics of HTLV-1 infection among an isolated, highly endemic population of African origin in French Guiana. Int. J. Cancer 76, 331-336.

Plumelle, Y., Pascaline, N., Nguyen, D., Panelatti, G., Jouannelle, A., Jouault, H., et al. (1993). Adult Tcell leukemia-lymphoma: a clinicopathologic study of twenty-six patients from Martinique. Hematol. Pathol. 7, 251-262.

Poiesz, B. J., Papsidero, L. D., Ehrlich, G., Sherman, M., Dube, S., Poiesz, M., et al. (2001). Prevalence of HTLV-Iassociated T-cell lymphoma. Am. J. Hematol. 66, 32-38.

Poiesz, B. J., Ruscetti, F. W., Gazdar, A. F., Bunn, P. A., Minna, J. D., and Gallo, R. C. (1980). Detection and isolation of type $\mathrm{C}$ retrovirus particles from fresh and cultured lymphocytes of a patient with cutaneous T-cell lymphoma. Proc. Natl. Acad. Sci. U.S.A. 77, 7415-7419.

Polizzotto, M. N., Wood, E. M., Ingham, H., and Keller, A. J. (2008). Reducing the risk of transfusion-transmissible viral infection through blood donor selection: the Australian experience 2000 through 2006. Transfusion 48, 55-63.

Poljak, M., Bednarik, J., Rednak, K., Seme, K., Kristancic, L., and CelanLucu, B. (1998). Seroprevalence of human T cell leukaemia/lymphoma virus type I (HTLV-I) in pregnant women, patients attending venereological outpatient services and intravenous drug users from Slovenia. Folia Biol. (Praha) 44, 23-25.

Pombo De Oliveira, M. S. (1996). HTLV-1 infection and adultT-cell leukemia in Brazil: an overview. Sao. Paulo Med. J. 114, 1177-1185.

Porter, K. R., Anthony, R. L., Solihin, A. and Hayes, C. G. (1995). Mapping of a human T-lymphotropic virus type I gag protein epitope that crossreacts with anti-Plasmodium falciparum antibodies. J. Med. Virol. 45, 469-474.

Pouliquen, J. F., Hardy, L., Lavergne, A., Kafiludine, E., and Kazanji, M. (2004). High seroprevalence of human T-cell lymphotropic virus type 1 in blood donors in Guyana and molecular and phylogenetic analysis of new strains in the Guyana shelf (Guyana, Suriname, and French Guiana). J. Clin. Microbiol. 42, 2020-2026.

Power, C., Weinshenker, B. G., Dekaban, G. A., Ebers, G. C., Francis, G. S., and Rice, G. P. (1989). HTLV-1 associated myelopathy in Canada. Can. J. Neurol. Sci. 16, 330-335.

Proietti, F. A., Carneiro-Proietti, A. B. Catalan-Soares, B. C., and Murphy, E. L. (2005). Global epidemiology of HTLV-I infection and associated diseases. Oncogene 24, 6058-6068.

Qiu, X., Hodges, S., Lukaszewska, T., Hino, S., Arai, H., Yamaguchi, J., et al. (2008). Evaluation of a new, fully automated immunoassay for detection of HTLV-I and HTLV-II antibodies. J. Med. Virol. 80, 484-493.

Quispe, N. C., Feria, E. B., SantosFortuna Ede, L., and Caterino-deAraujo, A. (2009). Confirming the presence of HTLV-1 infection and the absence of HTLV-2 in blood donors from Arequipa, Peru. Rev. Inst. Med. Trop. Sao Paulo 51, 25-29.

Rafatpanah, H., Hedayati-Moghaddam, M. R., Fathimoghadam, F., Bidkhori, H. R., Shamsian, S. K., Ahmadi, S., et al. (2011). High prevalence of HTLV-I infection in Mashhad, Northeast Iran: a population-based seroepidemiology survey. J. Clin. Virol. 52, 172-176.

Rajabalendaran, N., Burns, R., Mollison, L. C., Blessing, W., Kirubakaran,
M. G., and Lindschau, P. (1993). Tropical spastic paraparesis in an aborigine. Med. J. Aust. 159, 28-29.

Ramalingam, S., Kannangai, R., Prakash, K. J., Ajithkumar, K., Jacob, M., George, R., et al. (2001). A pilot study of HTLV-I infection in high-risk individuals \& their family members from India. Indian J. Med. Res. 113, 201-209.

Re, M. C., Tommaseo, M., Furlini, G. and La Placa, M. (1989). High prevalence of serum antibody against human $\mathrm{T}$ cell leukemia virus type I (HTLV-I) among the Bismam Asmat population (Indonesian New Guinea). AIDS Res. Hum. Retroviruses 5, 551-554.

Reddy, D., Okochi, K., Woodfield, D. G., and Judd, W. (1987). Absence of HTLV I from New Zealand. J. Med. Virol. 22, 375-378.

Reeves, W. C., Levine, P. H., Cuevas, M., Quiroz, E., Maloney, E., and Saxinger, W. C. (1990). Seroepidemiology of human T cell lymphotropic virus in the Republic of Panama. Am. J. Trop. Med. Hyg. 42, 374-379.

Riedel, D. A., Evans, A. S., Saxinger, C., and Blattner, W. A. (1989). A historical study of human $\mathrm{T}$ lymphotropic virus type I transmission in Barbados. J. Infect. Dis. 159, 603-609.

Rio, B., Louvet, C., Gessain, A., Dormont, D., Gisselbrecht, C., Martoia, R., et al. (1990). Adult Tcell leukemia and non-malignant adenopathies associated with HTLV I virus. Apropos of 17 patients born in the Caribbean region and Africa. Presse Med. 19, 746-751.

Rodgers-Johnson, P., Morgan, O. S., Mora, C., Sarin, P., Ceroni, M., Piccardo, P., et al. (1988). The role of HTLV-I in tropical spastic paraparesis in Jamaica. Ann. Neurol. 23(Suppl.), S121-S126.

Roman, G. C., Schoenberg, B. S., Madden, D. L., Sever, J. L., Hugon, J., Ludolph, A., et al. (1987). Human Tlymphotropic virus type I antibodies in the serum of patients with tropical spastic paraparesis in the Seychelles. Arch. Neurol. 44, 605-607.

Roucoux, D. F., Wang, B., Smith, D., Nass, C. C., Smith, J., Hutching, S. T., et al. (2005). A prospective study of sexual transmission of human $\mathrm{T}$ lymphotropic virus (HTLV)-I and HTLV-II. J. Infect. Dis. 191, 1490-1497.

Rouet, F., Foucher, C., Rabier, M., Gawronski, I., Taverne, D., Chancerel, B., et al. (1999a). Human T-lymphotropic virus type I among blood donors from Guadeloupe: donation, demographic, and 
biologic characteristics. Transfusion 39, 639-644.

Rouet, F., Rabier, R., Foucher, C., Chancerel, B., Agis, F., and Strobel, M. (1999b). Geographical clustering of human T-cell lymphotropic virus type I in Guadeloupe, an endemic Caribbean area. Int. J. Cancer 81, 330-334.

Safai, B., Huang, J. L., Boeri, E., Farid, R., Raafat, J., Schutzer, P., et al. (1996). Prevalence of HTLV type I infection in Iran: a serological and genetic study. AIDS Res. Hum. Retroviruses 12, 1185-1190.

Saito, M., Moritoyo, T., Park, J. H., Lee, B. I., Kim, J. S., Fujisawa, J., et al. (1993). Nucleotide sequence analysis of HTLV-I isolate from a Korean patient with HAM/TSP. Yonsei Med. J. 34, 321-327.

Salemi, M., Van Dooren, S., Audenaert, E., Delaporte, E., Goubau, P., Desmyter, J., et al. (1998). Two new human T-lymphotropic virus type I phylogenetic subtypes in seroindeterminates, a Mbuti pygmy and a Gabonese, have closest relatives among African STLV-I strains. Virology 246, 277-287.

Sanchez-Palacios, C., Gotuzzo, E., Vandamme, A. M., and Maldonado, Y. (2003). Seroprevalence and risk factors for human T-cell lymphotropic virus (HTLV-I) infection among ethnically and geographically diverse Peruvian women. Int. J. Infect. Dis. 7, 132-137.

Sanders, R. C., Wai'in, P. M., Alexander, S. S., Levin, A. G., Blattner, W. A., and Alpers, M. P. (1993). The prevalence of antibodies to human T-lymphotropic virus type I in different population groups in Papua New Guinea. Arch. Virol. 130, 327-334.

Sarkodie, F., Adarkwa, M., AduSarkodie, Y., Candotti, D., Acheampong, J. W., and Allain, J. P. (2001). Screening for viral markers in volunteer and replacement blood donors in West Africa. Vox Sang. 80, 142-147.

Satake, M., Yamaguchi, K., and Tadokoro, K. (2012). Current prevalence of HTLV-1 in Japan as determined by screening of blood donors. J. Med. Virol. 84, 327-335.

Saxinger, W., Blattner, W. A., Levine, P. H., Clark, J., Biggar, R., Hoh, M., et al. (1984). Human T-cell leukemia virus (HTLV-I) antibodies in Africa. Science 225, 1473-1476.

Schill, P. H., Bruneau, B., Le Page, B., Humeau, O., Grimault, C., Tampreau, V., et al. (1989). Seroprevalence of anti-HIV antibodies in a rural Haitian population. Bull. Soc. Pathol. Exot. Filiales 82, 308-315.

Schreiber, G. B., Murphy, E. L., Horton, J. A., Wright, D. J., Garfein, R., Chien, H. C., et al. (1997). Risk factors for human T-cell lymphotropic virus types I and II (HTLV-I and -II) in blood donors: the retrovirus epidemiology donor study. NHLBI retrovirus epidemiology donor study. J. Acquir. Immune Defic. Syndr. Hum. Retrovirol. 14, 263-271.

Schrijvers, D., Delaporte, E., Peeters, M., Dupont, A., and Meheus, A. (1991). Seroprevalence of retroviral infection in women with different fertility statuses in Gabon, western equatorial Africa. J. Acquir. Immune Defic. Syndr. 4, 468-470.

Segurado, A., Granade, T., Parekh, B., Nunez, C. A., Meza, R., Amador, L., et al. (1997). Presence of HTLV-I and HTLV-II infection in Honduras. $J$. Acquir. Immune Defic. Syndr. Hum. Retrovirol. 16, 308.

Sene-Diouf, F., Ndiaye, M., Diop, A. G., Thiam, A., Ndao, A. K., Diagne, M., et al. (2000). Epidemiological, clinical and progressive aspects of neurological manifestations associated with retroviral infections: eleven year retrospective study. Dakar Med. $45,162-166$.

Seniuta, N. B., Iakovleva, L. S., Stepina, V. N., Buachidze, L. N., Gurova, E. P., Kologrivova, Z. A., et al. (1990). Screening of sera from the adult populations of some USSR regions for antibodies to the human T-cell leukemia virus type I (HTLV-I). Vopr. Virusol. 35, 309-312.

Senyuta, N., Syrtsev, A., Yamashita, M., Stepina, V., Susova, O., Scherbak, L., et al. (1998). Sero-epidemiologic and phylogenetic studies of HTLVI infection in 2 countries of the Caspian Sea region. Int. J. Cancer 77, 488-493.

Sertoz, R., Turhan, A., Bozkurt, H., Samlioglu, P., Degirmenci, A., Aydinok, Y., et al. (2010). Investigation of anti-HTLV I/II seroprevalence in healthy blood donors in Izmir region, Turkey. Mikrobiyol. Bul. 44, 579-584.

Seyfert, S., Faulstich, A., and Marx, P. (2004). What determines the CSF concentrations of albumin and plasma-derived IgG? J. Neurol. Sci. 219, 31-33.

Shtalrid, M., Shvidel, L., Korenfeld, R., Duek, A., Landau, Z., and Berrebi, A. (2005). HTLV-1 associated adult T-cell leukemia/lymphoma in Israel: report of two patients of Romanian origin. Haematologica 90, ECR13.
Sidi, Y., Meytes, D., Shohat, B., Fenig, E., Weisbort, Y., Lee, H., et al. (1990). Adult T-cell lymphoma in Israeli patients of Iranian origin. Cancer 65, 590-593.

Silva Cabrera, E., Perez Guevara, M. T., Lubian Caballero, A. L., de la Fuente Arzola, J. L., Navea Leyva, L., and Cruz Sui, O. (1997). Search for antibodies against human $\mathrm{T}$ cell lymphotropic virus type I (HTLV-I) in blood donors and risk groups. Rev. Cubana. Med. Trop. 49, 24-27.

Singhal, B. S., Lalkaka, J. A., Sonoda, S., Hashimoto, K., Nomoto, M., Kubota, R., et al. (1993). Human Tlymphotropic virus type I infections in western India. AIDS 7, 138-139.

Stienlauf, S., Yahalom, V., Schwartz, E. Shinar, E., Segal, G., and Sidi, Y. (2009). Epidemiology of human Tcell lymphotropic virus type 1 infection in blood donors, Israel. Emerging Infect. Dis. 15, 1116-1118.

Stuver, S. O., Tachibana, N., Okayama, A., Shioiri, S., Tsunetoshi, Y., Tsuda, K., et al. (1993). Heterosexual transmission of human $\mathrm{T}$ cell leukemia/lymphoma virus type I among married couples in southwestern Japan: an initial report from the Miyazaki Cohort Study. J. Infect. Dis. 167, 57-65.

Tajima, K. (1990). The 4th nationwide study of adult T-cell leukemia/lymphoma (ATL) in Japan: estimates of risk of ATL and its geographical and clinical features. The T- and B-cell Malignancy Study Group. Int. J. Cancer 45, 237-243.

Tajima, K., Kamura, S., Ito, S., Ito, M., Nagatomo, M., Kinoshita, K., et al. (1987). Epidemiological features of HTLV-I carriers and incidence of ATL in an ATL-endemic island: a report of the community-based cooperative study in Tsushima, Japan. Int. J. Cancer 40, 741-746.

Takahashi, K., Takezaki, T., Oki, T., Kawakami, K., Yashiki, S., Fujiyoshi, T., et al. (1991). Inhibitory effect of maternal antibody on motherto-child transmission of human T-lymphotropic virus type I. The Mother-to-Child Transmission Study Group. Int. J. Cancer 49, 673-677.

Takao, S., Ishida, T., Bhatia, K. K., Saha, N., Soemantri, A., and Kayame, O. W. (2000). Seroprevalence of human Tlymphotropic virus type 1 in Papua New Guinea and Irian Jaya measured using different western blot criteria. J. Clin. Virol. 16, 129-133.

Takezaki, T., Tajima, K., Komoda, H., and Imai, J. (1995). Incidence of human $\mathrm{T}$ lymphotropic virus type I seroconversion after age 40 among Japanese residents in an area where the virus is endemic. J. Infect. Dis. $171,559-565$.

Tanggo, Y., Gultom, S. P., Simanjuntak, T., Sibuea, W. H., Matsuzaki, H., and Yamaguchi, K. (2000). Human $\mathrm{T}$ lymphotropic virus I in Indonesia. Very low seroprevalence in the Jakarta area: antibodies in healthy blood donors and in various nonhematological diseases. Intervirology $43,77-79$.

Taylor, G. P., Bodeus, M., Courtois, F., Pauli, G., Del Mistro, A., Machuca, A., et al. (2005). The seroepidemiology of human T-lymphotropic viruses: types I and II in Europe: a prospective study of pregnant women. J. Acquir. Immune Defic. Syndr. 38, 104-109.

Taylor, M. B., Parker, S. P., CreweBrown, H. H., McIntyre, J., and Cubitt, W. D. (1996). Seroepidemiology of HTLV-I in relation to that of HIV-1 in the Gauteng region, South Africa, using dried blood spots on filter papers. Epidemiol. Infect. 117, 343-348.

Temple, J. J., Brammer, M. G., Andes, W. A., Covington, S., and Rangan, S. (1986). Adult T-cell leukemialymphoma. Unusual features of two patients from a low-incidence area. Cancer 58, 694-698.

Thyss, A., Michiels, J. F., Ayela, P., Lagrange, M., Hoffman, P., and Schneider, M. (1990). Leukemia/lymphoma $\mathrm{T}$ syndrome associated with HTLV 1 in a patient of Moroccan origin. Presse Med. 19, 135.

Toro, C., Rodes, B., Aguilera, A., Caballero, E., Benito, R., Tuset, C., et al. (2002). Clinical impact of HTLV1 infection in Spain: implications for public health and mandatory screening. J. Acquir. Immune Defic. Syndr. 30, 366-368.

Tortevoye, P., Tuppin, P., Carles, G., Peneau, C., and Gessain, A. (2005). Comparative trends of seroprevalence and seroincidence rates of human $\mathrm{T}$ cell lymphotropic virus type I and human immunodeficiency virus 1 in pregnant women of various ethnic groups sharing the same environment in French Guiana. Am. J. Trop. Med. Hyg. 73, 560-565.

Tortevoye, P., Tuppin, P., Peneau, C., Carles, G., and Gessain, A. (2000). Decrease of human T-cell lymphotropic virus type I prevalence and low incidence among pregnant women from a high endemic ethnic group in French Guiana. Int. J. Cancer 87, 534-538. 
Trejo-Avila, L. M., FuentesPensamiento, R., Scorro FloresCastaneda, M., Diaz-Mendoza, M. L., Zapata-Benavides, P., and TamezGuerra, R. S. (1996). Seroprevalence of HTLV-I/II in blood donors in Monterrey, Mexico. Arch. Med. Res. 27, 97-99.

Trenchi, A., Gastaldello, R., Balangero, M., Irizar, M., Cudola, A., and Gallego, S. (2007). Retrospective study of the prevalence of human $\mathrm{T}$ cell lymphotropic virus-type $1 / 2$, $\mathrm{HIV}$, and HBV in pregnant women in Argentina. J. Med. Virol. 79, 1974-1978.

Trevino, A., Aguilera, A., Caballero, E., Benito, R., Parra, P., Eiros, J. M., et al. (2012). Trends in the prevalence and distribution of HTLV-1 and HTLV-2 infections in Spain. Virol. J. 9, 71.

Trujillo, J. M., Concha, M., Munoz, A., Bergonzoli, G., Mora, C., Borrero, I., et al. (1992). Seroprevalence and cofactors of HTLV-I infection in Tumaco, Colombia. AIDS Res. Hum. Retroviruses 8, 651-657.

Tseliou, P. M., Spanakis, N., Spiliotakara, A., Markogiannakis, A., Legakis, N. J., and Tsakris, A. (2006). Prevalence of infection by HTLV-I/II among pregnant women and highrisk groups in the Peloponnese peninsula, Greece. Int. J. STD AIDS 17, 543-546.

Tseliou, P. M., Spiliotakara, A., Politis, C., Spanakis, N., Legakis, N. J., and Tsakris, A. (2004). Prevalence of human T-cell lymphotropic virus-I/II-indeterminate reactivities in a Greek blood bank population. Transfus Med 14, 253-254.

Tuppin, P., Makuwa, M., Guerma, T., Bazabana, M. M., Loukaka, J. C., Jeannel, D., et al. (1996). Low HTLV-I/II seroprevalence in pregnant women in Congo and a geographic cluster of an HTLV-like indeterminate western blot pattern. J. Acquir. Immune Defic. Syndr. Hum. Retrovirol. 11, 105-107.

Tuset, C., Gutierrez, M., Carbonell, C., Tuset, T., and Soriano, V. (1997). Human T-cell lymphotropic virus infection in pregnant women in Spain. Eur. J. Clin. Microbiol. Infect. Dis. 16, 771-773.

Ueda, K., Kusuhara, K., Tokugawa, K., Miyazaki, C., Yoshida, C., Tokumura, K., et al. (1989). Cohort effect on HTLV-I seroprevalence in southern Japan. Lancet 2, 979.

Umemoto, M., Take, H., Kusuhara, K., and Kuraya, K. (1994). Marriage patterns among HTLV-I seropositive women in Japan. Cancer Lett. 81, 237-240.
Ureta-Vidal, A., Angelin-Duclos, C., Tortevoye, P., Murphy, E., Lepere, J. F., Buigues, R. P., et al. (1999). Mother-to-child transmission of human T-cell-leukemia/lymphoma virus type I: implication of high antiviral antibody titer and high proviral load in carrier mothers. Int. J. Cancer 82, 832-836

Vallejo, A., Dubon, J. M., and GarciaSaiz, A. (1996). Presence of human T-cell lymphotropic virus types I and II infections in Honduras. $J$. Acquir. Immune Defic. Syndr. Hum. Retrovirol. 12, 529-530.

van der Ryst, E., Joubert, G., Smith, M. S., Terblanche, M., Mollentze, F., and Pretorius, A. M. (1996). HTLV-I infection in the Free State region of South Africa: a sero-epidemiologic study. Cent. Afr. J. Med. 42, 65-68.

van Doornum, G. J., Hooykaas, C., Huisman, J. G., van der Linden, M. M., and Coutinho, R. A. (1990). Prevalence of human Tcell leukemia virus antibody among heterosexuals living in Amsterdam, The Netherlands. J. Med. Virol. 32, 183-188.

Vandamme, A. M., Salemi, M., and Desmyter, J. (1998). The simian origins of the pathogenic human T-cell lymphotropic virus type I. Trends Microbiol. 6, 477-483.

Vasquez, P., Sanchez, G., Volante, C., Vera, L., Ramirez, E., Soto, G., et al. (1991). Human Tlymphotropic virus type I: new risk for Chilean population. Blood 78, 850-851.

Veelken, H., Kohler, G., Schneider, J., Dierbach, H., Mertelsmann, R., Schaefer, H. E., et al. (1996). HTLV-I-associated adult $\mathrm{T}$ cell leukemia/lymphoma in two patients from Bucharest, Romania. Leukemia 10, 1366-1369.

Verdier, M., Bonis, J., and Denis, F. (1994). "The Prevalence and Incidence of HTLVs in Africa," in AIDS in Africa, eds M. Essex, S. Mboup, P. Kanki, and M. Kalengayi (New York: Raven Press, Ltd.), 173-192.

Verdier, M., Denis, F., Sangare, A., Barin, F., Gershy-Damet, G., Rey, J. L., et al. (1989). Prevalence of antibody to human $\mathrm{T}$ cell leukemia virus type 1 (HTLV-1) in populations of Ivory Coast, West Africa. J. Infect. Dis. 160, 363-370.

Verdonck, K., Gonzalez, E., Van Dooren, S., Vandamme, A. M., Vanham, G., and Gotuzzo, E. (2007). Human T-lymphotropic virus 1: recent knowledge about an ancient infection. Lancet. Infect. Dis. 7, 266-281.
Vernant, J. C., Maurs, L., Gessain, A., Barin, F., Gout, O., Delaporte, J. M., et al. (1987). Endemic tropical spastic paraparesis associated with human T-lymphotropic virus type I: a clinical and seroepidemiological study of 25 cases. Ann. Neurol. 21, 123-130.

Voevodin, A., al-Mufti, S., Farah, S., Khan, R., and Miura, T. (1995). Molecular characterization of human T-lymphotropic virus, type 1 (HTLV-1) found in Kuwait: close similarity with HTLV-1 isolates originating from Mashhad, Iran. AIDS Res. Hum. Retroviruses 11, 1255-1259.

Vrielink, H., and Reesink, H. W. (2004). HTLV-I/II prevalence in different geographic locations. Transfus. Med. Rev. 18, 46-57.

Wang, H. R., Yan, Y. S., Zhang, Q. W. Zheng, J., Liu, J. M., Feng, Y. Y., et al. (2004). Sero-epidemiological study on the human T-cell leukaemia virus type I/II infection in the east coastal areas of Fujian province. Zhonghua Liu Xing Bing Xue Za Zhi 25, 428-430.

Wang, Y., Li, X., Song, A., Zhang, C., Chen, Y., Chen, C., et al. (2005). Prevalence and partial sequence analysis of human $\mathrm{T}$ cell lymphotropic virus type I in China. J. Med. Virol. 76 613-618.

Watanabe, T. (2011). Current status of HTLV-1 infection. Int. J. Hematol. 94, 430-434.

Watanabe, T., Seiki, M., Tsujimoto, H., Miyoshi, I., Hayami, M., and Yoshida, M. (1985). Sequence homology of the simian retrovirus genome with human T-cell leukemia virus type I. Virology 144, 59-65.

Whyte, G. S. (1997). Is screening of Australian blood donors for HTLVI necessary? Med. J. Aust. 166, 478-481.

Wiktor, S. Z., Pate, E. J., Murphy, E. L., Palker, T. J., Champegnie, E., Ramlal, A., et al. (1993). Mother-to-child transmission of human T-cell lymphotropic virus type I (HTLV-I) in Jamaica: association with antibodies to envelope glycoprotein (gp46) epitopes. J. Acquir. Immune Defic. Syndr. 6, 1162-1167.

Wiktor, S. Z., Piot, P., Mann, J. M., Nzilambi, N., Francis, H., Vercauteren, G., et al. (1990). Human T cell lymphotropic virus type I (HTLVI) among female prostitutes in Kinshasa, Zaire. J. Infect. Dis. 161, 1073-1077.

Williams, A. E., Fang, C. T., Slamon, D. J., Poiesz, B. J., Sandler,
S. G., Darr, W. F. II, et al. (1988). Seroprevalence and epidemiological correlates of HTLV-I infection in U.S. blood donors. Science 240, 643-646.

Williams, C. K., Alexander, S. S., Bodner, A., Levine, A., Saxinger, C., Gallo, R. C., et al. (1993). Frequency of adult T-cell leukaemia/lymphoma and HTLV-I in Ibadan, Nigeria. Br. J. Cancer 67, 783-786.

Williams, C. K., Dada, A., and Blattner, W. A. (1994). Some epidemiological features of the human T-cell lymphotropic virus type I (HTLV-I) and ATL in Nigerians. Leukemia 8 (Suppl. 1), S77-S82.

Wolfe, N. D., Heneine, W., Carr, J. K., Garcia, A. D., Shanmugam, V., Tamoufe, U., et al. (2005). Emergence of unique primate $\mathrm{T}$ lymphotropic viruses among central African bushmeat hunters. Proc. Natl. Acad. Sci. U.S.A. 102, 7994-7999.

Yamaguchi, K., Inaoka, T., Ohtsuka, R., Akimichi, T., Hongo, T., Kawabe, T., et al. (1993). HTLV-I, HIV-I, and hepatitis $\mathrm{B}$ and $\mathrm{C}$ viruses in Western Province, Papua New Guinea: a serological survey. Jpn. J. Cancer Res. 84, 715-719.

Yanagihara, E. T., Blaisdell, R. K., Hayashi, T., and Lukes, R. J. (1989). Malignant lymphoma in HawaiiJapanese: a retrospective morphologic survey. Hematol. Oncol. 7, 219-232.

Yanagihara, R. (1994). Geographicspecific genotypes or topotypes of human T-cell lymphotropic virus type I as markers for early and recent migrations of human populations. Adv. Virus Res. 43, 147-186.

Yanagihara, R., Ajdukiewicz, A. B., Garruto, R. M., Sharlow, E. R., Wu, X. Y., Alemaena, O., et al. (1991). Human T-lymphotropic virus type I infection in the Solomon Islands. Am. J. Trop. Med. Hyg. 44, 122-130.

Yanagihara, R., Jenkins, C. L., Alexander, S. S., Mora, C. A., and Garruto, R. M. (1990). Human T lymphotropic virus type I infection in Papua New Guinea: high prevalence among the Hagahai confirmed by western analysis. J. Infect. Dis. 162, 649-654.

Ydy, R. R., Ferreira, D., Souto, F. J., and Fontes, C. J. (2009). Prevalence of human T-cell lymphotropic virus (HTLV-1/2) infection among puerperae in Cuiaba, Mato Grosso, 2006. Rev. Soc. Bras. Med. Trop. 42, 28-32. 
Yim, M., Hayashi, T., Yanagihara, E., Kadin, M., and Nakamura, J. (1986). HTLV-I-associated T-cell leukemia in Hawaii. Am. J. Med. Sci. 292, 325-327.

Zaaijer, H. L., Cuypers, H. T., Dudok de Wit, C., and Lelie, P. N. (1994). Results of 1-year screening of donors in The Netherlands for human T-lymphotropic virus (HTLV) type I: significance of Western blot patterns for confirmation of HTLV infection. Transfusion 34, 877-880.

Zabaleta, M., Peralta, J., Birges, J., Bianco, N., and Echeverria de Perez, G. (1994). HTLV-I-associated myelopathy in Venezuela. $J$. Acquir. Immune Defic. Syndr. 7, 1289-1290.

Zaninovic, V., Arango, C., Biojo, R., Mora, C., Rodgers-Johnson,
P., Concha, M., et al. (1988). Tropical spastic paraparesis in Colombia. Ann. Neurol. 23(Suppl.), S127-S132.

Zaninovic, V., Sanzon, F., Lopez, F., Velandia, G., Blank, A., Blank, M., et al. (1994). Geographic independence of HTLV-I and HTLV-II foci in the Andes highland, the Atlantic coast, and the Orinoco of Colombia. AIDS Res. Hum. Retroviruses 10, 97-101.

Zhuo, J., Yang, T., Zeng, Y., and Lu, L. (1995). Epidemiology of anti-human T-cell leukemia virus type I antibody and characteristics of adult T-cell leukemia in China. Chin. Med. J. 108, 902-906.

Zoulek, G., Schatzl, H., Kawabata, M., de Cabral, M. B., Cabello,
A., Freutsmiedl, K., et al. (1992). A seroepidemiological survey of antibodies to HTLV-I/HTLV-II in selected population groups in Paraguay. Scand. J. Infect. Dis. 24, 397-398.

Zurita, S., Costa, C., Watts, D., Indacochea, S., Campos, P., Sanchez, J., et al. (1997). Prevalence of human retroviral infection in Quillabamba and Cuzco, Peru: a new endemic area for human T cell lymphotropic virus type 1. Am. J. Trop. Med. Hyg. 56, 561-565.

Conflict of Interest Statement: The authors declare that the research was conducted in the absence of any commercial or financial relationships that could be construed as a potential conflict of interest.
Received: 12 September 2012; paper pending published: 01 October 2012; accepted: 18 October 2012; published online: 15 November 2012.

Citation: Gessain $A$ and Cassar $O$ (2012) Epidemiological aspects and world distribution of HTLV-1 infection. Front. Microbio. 3:388. doi: 10.3389/fmicb.2012.00388

This article was submitted to Frontiers in Virology, a specialty of Frontiers in Microbiology.

Copyright (c) 2012 Gessain and Cassar. This is an open-access article distributed under the terms of the Creative Commons Attribution License, which permits use, distribution and reproduction in other forums, provided the original authors and source are credited and subject to any copyright notices concerning any third-party graphics etc. 